GEOLOGICAL SURVEY CIRCULAR 648

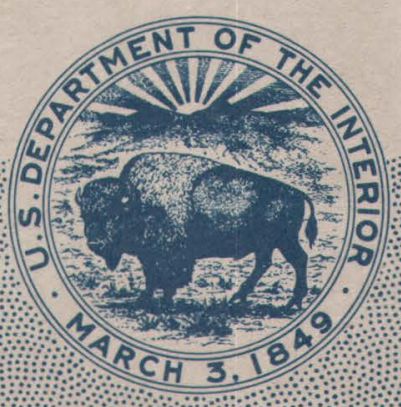

\title{
Reports and Maps of the \\ Geological Survey Released \\ Only in the Open Files, 1971
}





\section{Reports and Maps of the Geological Survey Released Only in the Open Files, 1971}

By Betsy A. Weld, Kathleen T. Iseri, and George W. Brett

GEOLOGICAL SURVEY CIRCULAR 648 
United States Department of the Interior ROGERS C. B. MORTON, Secretary

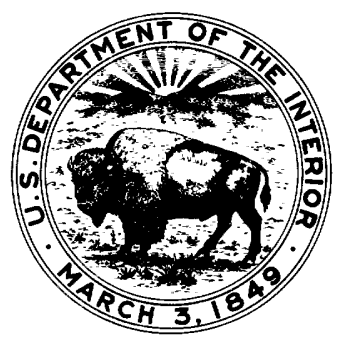

\section{Geological Survey}

V. E. McKelvey, Director 


\title{
Reports and Maps of the Geological Survey Released Only in the Open Files, 1971
}

\author{
By Betsy A. Weld, Kathleen T. Iseri, and George W. Brett \\ CONTENTS

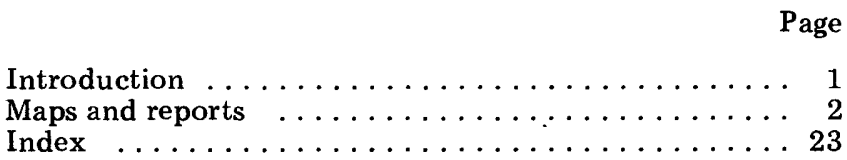

\section{INTRODUCTION}

This circular contains a list of maps and reports released by the U.S. Geological Survey during 1971 that are available for public inspection in the open files. These maps and reports may be consulted at the indicated depositories, and copies may be made upon request (at the requestor's expense).

The reports are arranged alphabetically by author; each report is preceded by a serial number that is used to identify the report in the index (p. 23), and is followed by the depositories at which it may be consulted.

Most open-file reports are on file in at least one of the major U.S. Geological Survey depositories listed below. Many are also on file at depositories selected as appropriate for the individual reports. All depositories are U.S. Geological Survey offices unless a State Geological Survey or other organization is specifically indicated. The following symbols are used in the list to indicate the major depositories:

A Public Inquiries Office, 108 Skyline Bldg., 508 2d Ave., Anchorage, Alaska 99501.

Da Library, Bldg. 25, Federal Center, Denver, Colo. 80225.

$\mathrm{Db}$ Public Inquiries Office, 1012 Federal Bldg., Denver, Colo. 80202.

F Library, 801 East Cedar Ave., Flagstaff, Ariz. 86001.

LA Public Inquiries Office, 7638 Federal Bldg., 300 North Los Angeles St., Los Angeles, Calif. 90012.
M Library, 345 Middlefield Rd., Menlo Park, Calif. 94025.

S Public Inquiries Office, 678 U.S. Court House Bldg., West 920 Riverside Ave., Spokane, Wash. 99201.

SF Public Inquiries Office, 504 Custom House, 555 Battery St., San Francisco, Calif. 94111.

$\mathrm{T}$ Public Inquiries Office, Rm. IC45, 1100 Commerce St., Dallas, Tex. 75202.

U Public Inquiries Office, 8102 Federal Office Bldg., 125 South State St., Salt Lake City, Utah 84111.

Wa Library, 1033 General Services Administration Bldg., 18 th and F Sts., NW., Washington, D.C. 20242.

Wb 132 Washington Bldg., Arlington Towers, 1011 Arlington Blvd., Arlington, Va. 22209.

Open-file reports released during past years have been listed in the following circulars (* indicates report is out of print):

\begin{tabular}{lr|rr} 
Years(s) & Circulars & Year & Circular \\
$1946-47$ & $* 56$ & 1960 & \\
1948 & $* 64$ & 1961 & 448 \\
$1949-50$ & $* 149$ & 1962 & 463 \\
1951 & $* 227$ & 1963 & 473 \\
1952 & $* 263$ & 1964 & 488 \\
1953 & $* 337$ & 1965 & 498 \\
1954 & $* 364$ & 1966 & 518 \\
1955 & $* 379$ & 1967 & 528 \\
1956 & $* 401$ & 1968 & 548 \\
1957 & $* 403$ & 1969 & 568 \\
1958 & 412 & 1970 & 618 \\
1959 & 428 & 1971 & 638 \\
& & & 648
\end{tabular}




\section{MAPS AND REPORTS}

1. Adolphson, D. G., and LeRoux, E. F., Head fluctuations in artesian wells in the northern Black Hills, South Dakota: 18 p., 5 figs. (Wa, Wb; Rm. 231, Federal Bldg., Huron, S. Dak. 57350.)

2. Alexander, J. M., Annual compilation and analysis of hydrologic data for Calaveras Creek, San Antonio River basin, Texas, 1969: 56 p., 2 figs. (Wa, Wb, T; Rm. 630, Federal Bldg., 300 East 8th St., Austin, Tex. 78701.)

3. Allen, H. E., and Noehre, A. W., Floods in Arlington Heights quadrangle, northeastern Illinois: Supplement to HA-67: 11 p., 1 pl., 6 figs. (Wa, Wb; 605 North Neil St., Champaign, Ill. 61820.)

4. Allen, H. E., and Noehre, A. W., Floods in Harvard Northeast quadrangle, northeastern Illinois: 9 p., 12 figs. (Wa, Wb; PO Box 1026, 605 North Neil St., Champaign, Ill. 61820.)

5. Anders, R. B., Electrical analog model study of water in the Yabucoa Valley, Puerto Rico, Phase 1-Collecting preliminary data and assembling available data: 47 p., 9 figs. (Wa, Wb; Bldg. 652, Fort Buchanan, P. R. 00934.)

6. Anderson, G. S., Ground-water exploration, Beaver Creek Valley, near Kenai, Alaska: 37 p., 13 figs. (Wa, Wb, A, LA, M, S, SF; 218 E St., Skyline Bldg., Anchorage, Alaska 99501.)

7. Anderson, G. S., and Jones, S. H., Lake-level fluctuations in the Kenai-Soldotna area, Alaska, 1967-71: 5 p., 3 figs. (Wa, Wb, M, A, SF, LA, S; Skyline Bldg., 218 E St., Anchorage, Alaska 99501.)

8. Anderson, Warren, Hydrologic considerations in draining Lake Apopka-A preliminary analysis, 1970, Florida: 29 p., 12 figs. (Wa, Wb; 903 West Tennessee St., Tallahassee, Fla. 32304; Rm. 244, Federal Bldg., 207 NW. 2d St., Ocala, Fla. 32670; Southwest Water Management Dist., PO Box 457, Brooksville, Fla. 33512; Florida Dept. Air and Water Pollution Control, 300 Tallahassee Bank Bldg., 315 South Calhoun, Tallahassee, Fla. 32301.)

9. Armstrong, A. K., Pennsylvanian carbonates, paleoecology and stratigraphy, north flank, eastern Brooks Range, Arctic Alaska: 25 p., 6 figs. (Wa, Da, Db, A, LA, M, S, SF; Brooks Bldg., College, Alaska 99701; Rm. 441,
Federal Bldg., Juneau, Alaska 99801; Alaska Div. Geol. Survey: Rm. 509, Goldstein Bldg., Juneau, Alaska 99801; 323 East 4th Ave., Anchorage, Alaska 99504; and University Ave., College, Alaska 99701.)

10. Ashley, R. P., Preliminary geologic map of the Goldfield mining district, Esmeralda and Nye Counties, Nevada: map with explanation and cross sections ( 1 sheet), scale $1: 24,000$. (Wa, Da, M, SF, LA, U; Library, Mackay School Mines, Univ. Nevada, Reno, Nev. 89507.)

11. Ashley, R. P., and Keith, W. J., Geochemical data for the Sixteen-to-One mine, near Silver Peak, Esmeralda County, Nevada: 18 p., 2 sheets (fig. 2), 14 p. tables. (Wa, Da, LA, M, SF, U; Library, Mackay School Mines, Univ. Nevada, Reno, Nev. 89507.)

12. Averett, R. C., Wood, P. R., and Muir, K. S., Water chemistry of the Santa Clara Valley, California: 24 p., 1 fig. (Wa, Wb, M, LA, SF; 855 Oak Grove Ave., Menlo Park, Calif. 94025.)

13. Barclay, C. S. V., Preliminary geologic map of the Dengate quadrangle, Morton County, North Dakota: Geologic map (scale 1:24,000), text, 2 sheets of stratigraphic sections, and map showing distribution of ganister blocks. (Wa, Da, Db; North Dakota Geological Survey office, Leonard Hall, Univ. North Dakota, Grand Forks, N. Dak. 58201.)

14. Barnes, D. F., Preliminary Bouguer anomaly and specific gravity maps of Seward Peninsula and Yukon Flats, Alaska: 11 p., 4 maps, scale 1:1,000,000. (Wa, Da, Db, A, LA, M, S, SF; Alaska Div. Geol. Survey: Rm. 509, Goldstein Bldg., Juneau, Alaska 99801; 323 East 4th Ave., Anchorage, Alaska 99504; University Ave., College, Alaska 99701.)

15. Basler, J. A., Annual water-resources review, White Sands Missile Range, 1970, a basic-data report: 33 p., 8 figs. (Wa, Wb, Db, T; Rm. 223, Geology Bldg., Univ. New Mexico, Albuquerque, N. Mex. 87106.)

16. Basler, J. A., Investigation of a water supply near Encino, New Mexico, during the STARMET test: 15 p., 2 figs. (Wa, Wb, Db, T; Rm. 223, Geology Bldg., Univ. New Mexico, Albuquerque, N. Mex. 87106.)

17. Batson, R. M., and Larson, K. B., Preliminary log of $70 \mathrm{~mm}$ pictures taken on the lunar surface 
during the Apollo 14 mission: Magazines II, JJ, KK, LL, MM, with Sample information, by R. L. Sutton: 31 p. (incl. 27 p. tables). (Wa, Da, F, M.)

18. Batson, R. M., Larson, K. B., Reed, V.S. Rennilson, J. J., Sutton, R. L., Tyner, R. L., Ulrich, G. E., and Wolfe, E. W., Preliminary catalog of pictures taken on the lunar surface during the Apollo 15 mission: $61 \mathrm{p}$, including 6 tables, 7 figs. (Wa, Da, Db, M, A, SF, LA, S, U.)

19. Bedinger, M. S., Sniegocki, R. T., and Poole, J. L., The thermal springs of Hot Springs National Park, Arkansas-factors affecting their environment and management: 74 p., 5 figs. (Wa, Wb, T; Rm. 2301, Federal Office Bldg., 700 West Capitol Ave., Little Rock, Ark. 72201.)

20. Behrendt, J. C., and Wotorson, C. S., Aeromagnetic map of the Bopolu quadrangle, Liberia: 2 sheets, scale 1:250,000. (Wa, Da, M.)

21. Behrendt, J. C., and Wotorson, C. S., Aeromagnetic map of the Buchanan quadrangle, Liberia: 2 sheets, scale 1:250,000. (Wa, Da, M.)

22. Behrendt, J. C., and Wotorson, C. S., Aeromagnetic map of the Gbanka quadrangle, Liberia: 1 sheet, 5 p., scale 1:250,000. (Wa, Da, M.)

23. Behrendt, J. C., and Wotorson, C.S., Aeromagnetic map of the Harper quadrangle, Liberia: 3 sheets, 5 p., scale 1:250,000. (Wa, Da, M.)

24. Behrendt, J. C., and Wotorson, C.S., Aeromagnetic map of the Monrovia quadrangle, Liberia: 2 sheets, 8 p., scale 1:250,000. (Wa, Da, M.)

25. Behrendt, J. C., and Wotorson, C. S., Aeromagnetic map of the Sanokole quadrangle, Liberia: 1 sheet, 6 p., scale 1:250,000. (Wa, Da, M.)

26. Behrendt, J. C., and Wotorson, C. S., Aeromagnetic map of the Voinjama quadrangle, Liberia: 2 sheets, 7 p., scale 1:250,000. (Wa, Da, M.)

27. Behrendt, J. C., and Wotorson, C. S., Aeromagnetic map of the Zorzor quadrangle, Liberia: 1 sheet, 7 p., scale 1:250,000. (Wa, Da, M.)
28. Behrendt, J. C., and Wotorson, C. S., Bouguer anomaly map of the Monrovia quadrangle, Liberia: 1 sheet, scale $1: 250,000,5$ p. (Wa, Da, M.)

29. Behrendt, J. C., and Wotorson, C. S., Total-count gamma radiation map of the Bopolu quadrangle, Liberia: 2 sheets, 5 p., scale $1: 250,000$. (Wa, Da, M.)

30. Behrendt, J. C., and Wotorson, C. S., Total-count gamma radiation map of the Buchanan quadrangle, Liberia: 1 map (2 sheets), scale $1: 250,000,5$ p. (Copy at scale of $1: 125,000$ included.) (Wa, Da, M.)

31. Behrendt, J. C., and Wotorson, C. S., Total-count gamma radiation map of the Gbanka quadrangle, Liberia: 1 sheet, scale 1:250,000, 5 p. (Copy at scale of 1:125,000 included.) (Wa, Da, M.)

32. Behrendt, J. C., and Wotorson, C. S., Total-count gamma radiation map of the Harper quadrangle, Liberia: 1 map (3 sheets), scale $1: 250,000,5 \mathrm{p}$. (Copy at scale of $1: 125,000$ included.) ( $\mathrm{Wa}, \mathrm{Da}, \mathrm{M}$.

33. Behrendt, J. C., and Wotorson, C. S., Total-count gamma radiation map of the Juazohn quadrangle, Liberia: 1 map (2 sheets), scale $1: 250,000,6 \mathrm{p}$. (Copy at scale of $1: 125,000$ included.) (Wa, Da, M.)

34. Behrendt, J. C., and Wotorson, C. S., Total-count gamma radiation map of the Monrovia quadrangle, Liberia: 2 sheets, 6 p., scale 1:250,000. (Wa, Da, M.)

35. Behrendt, J. C., and Wotorson, C. S., Total-count gamma radiation map of the Sanokole quadrangle, Liberia: 1 sheet, 5 p., scale 1:250,000. (Wa, Da, M.)

36. Behrendt, J. C., and Wotorson, C. S., Total-count gamma radiation map of the Voinjama quadrangle, Liberia: 2 sheets, 5 p., scale $1: 250,000$. (Wa, Da, M.)

37. Behrendt, J. C., and Wotorson, C. S., Total-count gamma radiation map of the Zorzor quadrangle, Liberia: 1 sheet, 6 p., scale 1:250,000. (Wa, Da, M.)

38. Berlin, G. L., Waveform and computer analysis of geographic phenomena recorded on color and color IR multispectral imagery from aerial and orbital altitudes: 157 p., 51 figs., 8 tables. (Wa, Da, F, M.) 
39. Bertoldi, G. L., Chemical quality of ground water in the Dos Palos-Kettleman City area, San Joaquin Valley, California: 45 p., 11 figs. (Wa, Db, M, LA, SF; 855 Oak Grove Ave., Menlo Park, Calif. 94025; Rm. W-2235 Federal Bldg., 2800 Cottage Way, Sacramento, Calif. 95825.)

40. Bertoldi, G. L., Determination of channel capacity of reaches of Ash and Berenda Sloughs and a reach of the Chowchilla River, Madera County, California: 61 p., 2 figs. (Wa, Wb, M, SF, LA; 855 Oak Grove Ave., Menlo Park, Calif. 94025.)

41. Bertoldi, G. L., and Blodgett, J. C., Determination of channel capacity of the Fresno River downstream from Hidden Damsite, Madera County, California: 38 p., 3 figs. (Wa, Wb, LA, M, SF; 855 Oak Grove Ave., Menlo Park, Calif. 94025.)

42. Beyer, L. A., The vertical gradient of gravity in vertical and near-vertical boreholes: $229 \mathrm{p}$., 50 figs., 14 tables. (Wa, Da, M.)

43. Black, D. F. B., Map showing structural features and dolomite occurrence in the Winchester quadrangle, Clark and Madison Counties, Kentucky: 1 sheet, scale 1:24,000. (Wa, Da, M; 710 West High St., Lexington, Ky. 40508; Kentucky Geol. Survey, Rm. 307, Mineral Industries Bldg., Univ. Kentucky, 120 Graham Ave., Lexington, Ky. 40506.)

44. Blake, M. C., Jr., Wright, R. H., and Wentworth, C. M., compilers, Preliminary geologic map of western Sonoma County and northernmost Marin County, California: map with index and explanation (5 sheets), scale 1:62,500. (Wa, Da, LA, M, SF; Library, California Div. Mines and Geology, Ferry Bldg., San Francisco, Calif. 94111; State Office Bldg., 107 South Broadway, Los Angeles, Calif. 90012.)

45. Blodgett, J. C., Water temperatures of California streams, Colorado Desert Subregion: 30 p., 4 figs. (Wa, Wb, M, SF, LA; 855 Oak Grove Ave., Menlo Park, Calif. 94025.)

46. Blodgett, J. C., Water temperatures of California streams, north coastal subregion: 92 p., 4 figs. (Wa, Wb, LA, M, SF; 855 Oak Grove Ave., Menlo Park, Calif. 94025.)

47. Blodgett, J. C., Water temperatures of California streams, Sacramento basin subregion: $161 \mathrm{p}$., 4 figs. (Wa, Wb, M, LA, SF; 855 Oak Grove Ave., Menlo Park, Calif. 94025.)
48. Blodgett, J. C., Water temperatures of California streams, San Francisco Bay subregion: 53 p., 4 figs. (Wa, Wb, M, SF, LA; 855 Oak Grove Ave., Menlo Park, Calif. 94025.)

49. Boettcher, A. J., Evaluation of the water supply at six sites in Curecanti Recreation area, southwestern Colorado: 43 p., 12 figs. (Wa, Wb, Da, Db.)

50. Borman, R. G., compiler, Preliminary map of probable well yields from bedrock in Wisconsin: 1 map. (Wa, Wb; Rm. 200, 1815 University Ave., Madison, Wis. 53706.)

51. Borman, R. G., compiler, Preliminary map of probable well yields from glacial deposits in Wisconsin: 1 map. (Wa, Wb; Rm. 200, 1815 University Ave., Madison, Wis. 53706.)

52. Borman, R. G., compiler, Preliminary map showing thickness of glacial deposits in Wisconsin: 1 map. (Wa, Wb; Rm. 200, 1815 University Ave., Madison, Wis. 53706.)

53. Brabb, E. E., Sonneman, H. S., and Switzer, J. R., Jr., compilers, Geologic map of the Mount Diablo-Bryon area, Contra Costa, Alameda, and San Joaquin Counties, California: map and explanation (2 sheets), scale 1:62,500. (Wa, Da, M, SF, LA; Library, California Div. Mines and Geology, Ferry Bldg., San Francisco, Calif. 94111; State Office Bldg., 107 South Broadway, Los Angeles, Calif. 90012.)

54. Brobst, D. A., Pinckney, D. M., and Sainsbury, C. L., Geology and geochemistry of the Sinuk River barite deposits, Seward Peninsula, Alaska: 29 p., 2 figs., 2 tables. (Wa, Da, Db, A, LA, M, S, SF; Brooks Bldg., College, Alaska 99701; Rm. 441, Federal Bldg., Juneau, Alaska 99801; Alaska Div. Geol. Survey: Rm. 509, Goldstein Bldg., Juneau, Alaska 99801; 323 East 4th Ave., Anchorage, Alaska 99504; University Ave., College, Alaska 99701.)

55. Brosgé, W. P., and Conradi, Arthur, Jr., Magnetic susceptibilities of crystalline rock samples, Yukon River-Porcupine River area, east-central Alaska: 8 p., 1 fig. (Wa, Da, Db, A, LA, M, S, SF; Brooks Bldg., College, Alaska 99701; Rm. 441, Federal Bldg., Juneau, Alaska 99801; Alaska Div. Geol. Survey: Rm. 509, Goldstein Bldg., Juneau, Alaska 99801; 323 East 4th Ave., Anchorage, Alaska 99504; University Ave., College, Alaska 99701.) 
56. Brosgé, W. P., and Reiser, H. N., Preliminary bedrock geologic map, Wiseman and eastern Survey Pass quadrangles, Alaska: map and explanation ( 2 sheets), scale $1: 250,000$. (Wa, $\mathrm{Da}, \mathrm{Db}, \mathrm{A}, \mathrm{LA}, \mathrm{M}, \mathrm{S}, \mathrm{SF}$; Brooks Bldg., College, Alaska 99701; Rm. 441, Federal Bldg., Juneau, Alaska 99801; Alaska Div. Geol. Survey: Rm. 509, Goldstein Bldg., Juneau, Alaska 99801; 323 East 4th Ave., Anchorage, Alaska 99504; and University Ave., College, Alaska 99701.)

57. Brown, G. F., Preliminary tectonic map of the Arabian Peninsula: 7 p., 1 map, scale $1: 10,000,000$. (Wa, Da, M.)

58. Brown, W. M., III, A preliminary investigation of suspended-sand discharge of the Russian River, Sonoma County, California: 11 p., 5 figs. (Wa, Wb, LA, M, SF; 855 Oak Grove Ave., Menlo Park, Calif. 94025.)

59. Bryant, Bruce, Miller, R. D., and Scott, G. R., Geologic map of the Indian Hills quadrangle, Jefferson County, Colorado: 59 p., 2 pls., 1 fig., scale $1: 24,000$. (Wa, $\mathrm{Da}, \mathrm{Db}, \mathrm{M}, \mathrm{U}$; Colorado Geol. Survey, 254 Columbine Bldg., 1845 Sherman St., Denver, Colo. 80203.)

60. Buckner, H. D., Annual compilation and analysis of hydrologic data for Mountain Creek, Trinity River basin, Texas, 1969: 9 p., 1 fig. (Wa, Wb, T; Rm. 630, Federal Bldg., 300 East 8th St., Austin, Tex. 78701.)

61. Callahan, J. E., Geology and coal resources of T. 6 S., R. 51 W., unsurveyed, Umiat principal meridian, in the Cape Beaufort coal field, northwestern Alaska: 18 p., 5 sheets (scale $1: 24,000$, coal sections, index map, 3 tables). (Wa, Da, M; Rm. 316, Skyline Bldg., 508 2d Ave., Anchorage, Alaska 99501; U.S. Bur. Mines, Douglas Island via Causeway, Juneau, Alaska 99801.)

62. Cannon, W. F., Geologic map of the Greenwood quadrangle, Michigan: 1 sheet, scale 1:12,000. (Wa, Da, M; Michigan Dept. of Natural Resources, Geological Survey Div., Stevens T. Mason Bldg., Lansing, Mich. 48926.)

63. Cannon, W. F., Geologic map of the Republic quadrangle, Michigan: 1 sheet, scale 1:12,000. (Wa, Da, M; Michigan Dept. Nat. Resources, Geological Survey Div., Stevens T. Mason Bldg., Lansing, Mich. 48926.)

64. Carroon, L. E., Cooperative State and Federal ground-water program in Mississippi: 5 p. (Wa, Wb; 430 Bounds St., Jackson, Miss. 39206.)
65. Cathcart, J. B., Phosphate investigations in Colombia, 1969: A progress report, with a note on the aluminous laterite deposits of the Department of Cauca: 44 p., 3 figs., 5 tables. (Wa, Da, M.)

66. Chapman, R. M., Weber, F. R., and Taber, Bond, Preliminary geologic map of the Livengood quadrangle, Alaska: map and explanation (2 sheets), scale 1:250,000. (Wa, Da, Db, A, LA, M, S, SF; Brooks Bldg., College, Alaska 99701; Rm. 441, Federal Bldg., Juneau, Alaska 99801; Alaska Div. Geol. Survey: Rm. 509, Goldstein Bldg., Juneau, Alaska 99801; 323 East 4th Ave., Anchorage, Alaska 99504; and University Ave., College, Alaska 99701.)

67. Clark, A. L., Berg, H. C., Grybeck, Donald, and Ovenshine, A. T., Reconnaissance geology and geochemistry of Forrester Island National Wildlife Refuge, Alaska: 9 p., 1 fig., scale 1:63,360, 1 table. (Wa, Da, Db, A, LA, M, S, SF; Brooks Bldg., College, Alaska 99701; Rm. 441, Federal Bldg., Juneau, Alaska 99801; Alaska Div. Geol. Survey: Rm. 509, Goldstein Bldg., Juneau, Alaska 99801; 323 East 4th Ave., Anchorage, Alaska 99504; University Ave., College, Alaska 99701.)

68. Clark, A. L., Condon, W. H., Hoare, J. M., and Sorg, D. H., Analyses of stream-sediment samples from the Taylor Mountains D-8 quadrangle, Alaska: 60 p. (incl. 50 p. tables), 1 pl. (Wa, Da, Db, A, LA, M, S, SF; Brooks Bldg., College, Alaska 99701; Rm. 441, Federal Bldg., Juneau, Alaska 99801; Alaska Div. Geol. Survey: Rm. 509, Goldstein Bldg., Juneau, Alaska 99801; 323 East 4th Ave., Anchorage, Alaska 99504; University Ave., College, Alaska 99701.)

69. Clark, L. D., Geologic map of the Negaunee Southwest quadrangle, Michigan: map and explanation, scale 1:24,000 ( 1 sheet). (Wa, Da, M; Michigan Dept. Nat. Resources, Geological Survey Div., Stevens T. Mason Bldg., Lansing, Mich. 48926.)

70. Clark, S. H. B., and Bartsch, S. R., Reconnaissance geologic map and geochemical analyses of stream sediment and rock samples of the Anchorage B-6 quadrangle, Alaska: 63 p. (incl. 55 tables), 2 figs. (Wa, $\mathrm{Da}, \mathrm{Db}, \mathrm{A}$, LA, M, S, SF; Brooks Bldg., College, Alaska 99701; Rm. 441, Federal Bldg., Juneau, Alaska 99801; Alaska Div. Geol. Survey: Rm. 509, Goldstein Bldg., Juneau, Alaska 99801; 323 East 4th Ave., Anchorage, Alaska 99504; University Ave., College, Alaska 99701.) 
71. Clark, S. H. B., and Bartsch, S. R. Reconnaissance geologic map and geochemical analyses of stream sediment and rock samples of the Anchorage B-7 quadrangle, Alaska: 70 p., 2 figs. (Wa, Da, Db, A, LA, M, S, SF Brooks Bldg., College, Alaska 99701; Rm. 441, Federal Bldg., Juneau, Alaska 99801; Alaska Div. Geol. Survey: Rm. 509, Goldstein Bldg., Juneau, Alaska 99801; 323 East 4th Ave., Anchorage, Alaska 99504; and University Ave., College, Alaska 99701.)

72. Cobb, E. H., compiler, Metallic mineral resources map of the Mount McKinley quadrangle, Alaska: 6 p. (incl. 5 p. tables), 1 index map, scale 1:250,000. (Wa, Da, Db, A, LA, M, S, SF; Brooks Bldg., College, Alaska 99701; Rm. 441, Federal Bldg., Juneau, Alaska 99801; Alaska Div. Geol. Survey: Rm. 509, Goldstein Bldg., Juneau, Alaska 99801; 323 East 4th Ave., Anchorage, Alaska 99504; University Ave., College, Alaska 99701.)

73. Colton, R. B., Surficial geologic map of the $\mathrm{H}$ a $m$ p d e $n \quad q u$ a $d r a n g l e$, Massachusetts-Connecticut: Map, scale 1:24,000 (3 sheets). (Wa, Da, M; 80 Broad St., Boston, Mass. 02110; Connecticut Geol. and Nat. History Survey, Wesleyan Univ., Middletown, Conn. 06547.)

74. Colton, R. B., Surficial materials data and Quaternary geologic history of the Broad Brook quadrangle, Connecticut: $10 \mathrm{p}$., 1 location map, 1 table. (Wa; 80 Broad St. Boston, Mass. 02110; Connecticut Geol. and Nat. History Survey, Wesleyan Univ., Middletown, Conn. 06457.)

75. Colton, R. B., and Mallory, M. J., Analytical data from samples of surficial deposits, Hampden quadrangle, Massachusetts-Connecticut: map and table (2 sheets). (Wa; 80 Broad St., Boston, Mass. 02110; Connecticut Geol. Nat. History Survey, Wesleyan Univ., Middletown, Conn. 06457.)

76. Conger, D. H., Estimating magnitude and frequency of floods in Wisconsin: $206 \mathrm{p}$., 21 figs. (Wa, Wb; Rm. 200, 1815 University Ave., Madison, Wis. 53706.)

77. Cook, M. F., and Forbes, M. J., Jr., A proposed streamflow-data program for Louisiana: 62 p., 3 figs. (Wa, Wb, T; 6554 Florida Blvd., Baton Rouge, La. 70806.)

78. Cox, D. P., and Briggs, R. P., Geologic and metallogenic maps of Puerto Rico: 35 p., 2 pls., 1 table (15 p.), scale 1:240,000. (Wa;
Lamar St. and Franklin Roosevelt Ave., San Juan, P. R. 00963; Puerto Rico Econ. Devel. Admin., Industrial Research Dept., San Juan, P. R. 00963.)

79. Cressler, C. W., Maps of Gordon, Whitfield, and Murray Counties, Georgia, showing geology and location of wells and springs: 3 maps. (Wa, Wb; Rm 301, 900 Peachtree St., NE., Atlanta, Ga. 30309.)

80. Crippen, J. R., and Beall, R. M., A proposed streamflow-data program for California: 109 p. (incl. app.), 3 figs. (Wa, Wb, LA, M, SF ; 855 Oak Grove Ave., Menlo Park, Calif. 94025.)

81. Crosby, O. A., Thermal study of the Missouri River in North Dakota using infrared imagery: 51 p., 13 figs. (Wa, Wb; Rm. 348, New Federal Bldg., 3d St. and Rosser Ave., Bismarck, N. Dak. 58501.)

82. Csejtey, Béla, Jr., Patton, W. W., Jr., and Miller, T.P., Cretaceous plutonic rocks of St. Lawrence Island, Alaska a preliminary report: 20 p., 3 maps, 1 table. (Wa, Da, Db, A, LA, M, S, SF; Brooks Bldg., College, Alaska 99701; Rm. 441, Federal Bldg., Juneau, Alaska 99801; Alaska Div. Geol. Survey: Rm. 509, Goldstein Bldg., Juneau, Alaska 99801; 323 East 4 th Ave., Anchorage, Alaska 99504; University Ave., College, Alaska 99701.)

83. Dean, W. W., Water-quality and quantity data, East Fork Kaweah River basin, California, 1969: 29 p., 5 figs. (Wa, Wb, M, SF, LA; 855 Oak Grove Ave., Menlo Park, Calif. 94025.)

84. Dempster, G. R., Jr., and Massey, B. C., Annual compilation and analysis of hydrologic data for urban studies in the Fort Worth, Texas, metropolitan area, 1969: 50 p., 3 figs. (Wa, Wb, T; Rm. 630, Federal Bldg., 300 East 8th St., Austin, Tex. 78701.)

85. Detterman, R. L., Arctic Mesozoic correlation chart: 1 chart. (Wa, Da, Db, A, LA, M, S, SF; Brooks Bldg., College, Alaska 99701; Rm. 441, Federal Bldg., Juneau, Alaska 99801; Alaska Div. Geol. Survey: Rm. 509, Goldstein Bldg., Juneau, Alaska 99801; 323 East 4th Ave., Anchorage, Alaska 99504; University Ave., College, Alaska 99701.)

86. Diaz, J. R., Electric analog model study of water in the Guayama area, Puerto Rico, Phase 1: 68 p., 9 figs. (Wa, Wb; Bldg. 652, Fort Buchanan, P. R. 00934.) 
87. Dibblee, T. W., Jr., Geologic maps of seventeen 15-minute quadrangles $(1: 62,500)$ along the San Andreas fault in vicinity of King City, Coalinga, Panoche Valley, and Paso Robles, California, with index map. (Quadrangles are Adelaida, Bradley, Bryson, Coalinga, Greenfield, Hernandez Valley, Joaquin Rocks, King City, New Idria, Panoche Valley, Parkfield, Paso Robles, Polvadero Gap, Priest Valley, "Reef Ridge," San Ardo, San Miguel.) 17 sheets, index map. (Wa, Da, LA, M, SF; Library, California Div. Mines and Geol., Ferry Bldg., San Francisco, Calif. 94111; State Office Bldg., 107 South Broadway, Los Angeles, Calif. 90012.)

88. Dibblee, T. W., Jr., Regional geologic map of San Andreas and related faults in eastern San Gabriel Mountains, San Bernardino Mountains, western San Jacinto Mountains and vicinity, Los Angeles, San Bernardino, and Riverside Counties, California: map and explanation ( 1 sheet), scale $1: 250,000$. (Wa, $\mathrm{Da}, \mathrm{M}, \mathrm{LA}, \mathrm{SF}$; Library, California Div. Mines and Geology, Ferry Bldg., San Francisco, Calif. 94111; State Office Bldg., 107 South Broadway, Los Angeles, Calif. 90012.)

89. Doe, B. R., A list of references on lead isotope geochemistry, 1967-69 (with an addendum to the list through 1966): $28 \mathrm{p}$. (Wa, Da, M.)

90. Dorr, J. V. N., 3d, Hoover, D. B., Offield, T. W., Shacklette, H. T., The application of geochemical, botanical, geophysical, and remote sensing mineral prospecting techniques to tropical areas-State of the art and needed research: 95 p., 2 figs., 2 tables. (Wa, $\mathrm{Da}, \mathrm{M}$.

91. Dutro, J. T., Jr., Reiser, H. N., Detterman, R. L., and Brosge, W. P., Early Paleozoic fossils in the Neruokpuk Formation, northeast Alaska: 5 p. (Wa, Da, Db, M, A, SF, LA, S; Brooks Bldg., College, Alaska 99701; Rm. 441, Federal Bldg., Juneau, Alaska, 99801; Alaska Div. of Geological Survey: Rm 509, Goldstein Bldg., Juneau, Alaska 99801; 323 East 4th Ave., Anchorage, Alaska 99504; University Ave., College, Alaska 99701.)

92. Dutton, C. E., and Bradley, R. E., Bibliography of Precambrian geology of Wisconsin 1778-1968: 28 p. (Wa, Da, M; Wisconsin Geol. and Nat. History Survey, Univ. Wisconsin, 1815 University Ave., Madison, Wis. 53706.)

93. Dyer, K. L., and Young, H. W., A reconnaissance of the quality of water from irrigation wells and springs in the Snake Plain aquifer, southeastern Idaho: 29 p., 5 figs. ( Wa, Wb, M, SF, S, U; Rm. 365, Federal Bldg., 550 West Fort St., Boise, Idaho 83702.)

94. Dyni, J. R., Beck, P. C., and Mountjoy, Wayne, Nahcolite analyses of three drill cores from the saline facies of the Green River Formation in northwest Colorado: $13 \mathrm{p}$. (incl. 9 p. tables), 1 fig. (Wa, Da, Db, M, U; Colorado Geol. Survey, Rm. 254, Columbine Bldg., 1845 Sherman St., Denver, Colo. 80203.)

95. Epstein, J. B., Geology of the Stroudsburg quadrangle and adjacent areas, Pennsylvania-New Jersey: 339 p., 6 pls., 109 figs., 3 tables. (Wa.)

96. Everett, D. E., Curves showing time of travel and passage time of a contaminant at downstream locations in the Mississippi River below Baton Rouge, Louisiana: 1 fig. (Wa, Wb, T; 6554 Florida Blvd., Baton Rouge, La. 70806.)

97. Ewart, C. J., An investigation of floods in Hawaii through September 30, 1970: 166 p., 5 figs. (Wa, Wb, LA, M, SF; Rm. 330, 1100 Ward Ave., Honolulu, Hawaii 96814.)

98. Eyre, L. A., An investigation by remote sensing of vacant and unutilized land in an urbanized coastal area of southeast Florida: 32 p., 16 figs. (Wa, Da, F, M.)

99. Eyton, J. R., A preliminary investigation of enhancement techniques using infrared ektachrome processed as a negative and a positive, TR 69-6 and 69-6A: 34 p., 16 figs. (Wa, Da, F, M.)

100. Faust, S. D., Stutz, Hansjakob, Aly, O. M., and Anderson, P. W., Recovery, separation, and identification of phenolic compounds from polluted waters: 49 p., 5 figs. (Wa, Wb; $\mathrm{Rm}$. 420, Federal Bldg., Trenton, N. J. 08607.)

101. Ferrians, O. J. Jr., Preliminary engineering geologic maps of the proposed trans-Alaska pipeline route, Beechey Point and Sagavanirktok quadrangles: 2 sheets ( 2 maps, explanation, scale $1: 125,000)$. (Wa, Da, Db, M, A, LA, S, SF; Brooks Bldg., College, Alaska 99701; Rm. 441, Federal Bldg., Juneau, Alaska 99801; Alaska Div. Geol. Survey: Rm. 509, Goldstein Bldg., Juneau, Alaska 99801; 323 East 4th Ave., Anchorage, Alaska 99504; University Ave., College, Alaska 99701.) 
102. Ferrians, O. J., Jr., Preliminary engineering geologic maps of the proposed trans-Alaska pipeline route, Gulkana quadrangle: 2 sheets ( 2 maps, explanation, scale 1:125,000). (Wa, $\mathrm{Da}, \mathrm{Db}, \mathrm{A}, \mathrm{M}, \mathrm{LA}, \mathrm{S}, \mathrm{SF}$; Brooks Bldg., College, Alaska 99701; Rm. 441, Federal Bldg., Juneau, Alaska 99801; Alaska Div. Geol. Survey: Rm. 509, Goldstein Bldg., Juneau, Alaska 99801; 323 East 4th Ave., Anchorage, Alaska 99504; University Ave., College, Alaska 99701.)

103. Ferrians, O. J., Jr., Preliminary engineering geologic maps of the proposed trans-Alaska pipeline route, Philip Smith Mountains quadrangle: 2 sheets ( 2 maps, explanation, scale 1:125,000). (Wa, Da, Db, A, M, LA, S, SF; Brooks Bldg., College, Alaska 99701; Rm. 441, Federal Bldg., Juneau, Alaska 99801; Alaska Div. Geol. Survey: Rm. 509, Goldstein Bldg., Juneau, Alaska 99801; 323 East 4 th Ave., Anchorage, Alaska 99504; University Ave., College, Alaska 99701.)

104. Ferrians, O. J., Jr., Preliminary engineering geologic maps of the proposed trans-Alaska pipeline route, Valdez quadrangle: 2 sheets ( 2 maps, explanation, scale $1: 250,000$ ). Wa, $\mathrm{Da}, \mathrm{Db}, \mathrm{A}, \mathrm{M}, \mathrm{LA}, \mathrm{S}, \mathrm{SF}$; Brooks Bldg., College, Alaska 99701; Rm. 441, Federal Bldg., Juneau, Alaska 99801; Alaska Div. Geol. Survey: Rm. 509, Goldstein Bldg., Juneau, Alaska 99801; 323 East 4th Ave., Anchorage, Alaska 99504; University Ave., College, Alaska 99701.)

105. Feulner, A. J., Childers, J. M., and Norman, V. W., Water resources of Alaska: $130 \mathrm{p}$., 18 figs. (Wa, Wb, A, LA, M, SF; Skyline Bldg., 218 E St., Anchorage, Alaska 99501.)

106. Finnell, T. L., Preliminary geologic map of the Empire Mountains quadrangle, Pima County, Arizona: 1 map ( 2 sheets), scale $1: 48,000$. (A, $\mathrm{Da}, \mathrm{Db}, \mathrm{LA}, \mathrm{M}, \mathrm{SF}, \mathrm{U}$; Arizona Bur. Mines, Univ. Arizona, Tucson, Ariz. 85721.)

107. Flint, R. F., Fluvial sediment in North Fork Broad River subwatershed No. 14 (tributary to Toms Creek), Georgia: 26 p., 5 figs. (Wa, Wb; Rm. 301, 900 Peachtree St., NE., Atlanta, Ga. 30309.)

108. Flippo, H. N., Jr., Acidity control in Bald Eagle Creek and West Branch Susquehanna River, Clinton County, Pennsylvania: 25 p., 8 figs. (Wa, Wb; 228 Walnut St., Harrisburg, Pa. 17108.)
109. Flippo, H. N., Jr., Chemical and biological conditions in Bald Eagle Creek and prognosis of trophic characteristics of Foster Joseph Sayers Reservoir, Centre County, Pennsylvania: 48 p., 2 figs. (Wa, Wb; 228 Walnut St., Harrisburg, Pa. 17108.)

110. Foster, H. L., Analyses of stream-sediment and rock samples from the eastern part of the Eagle quadrangle, east-central Alaska: 54 p. (incl. 44 p. tables, 2 figs.). (Wa, $\mathrm{Da}, \mathrm{Db}, \mathrm{A}$, LA, M, S, SF; Alaska Div. Geol. Survey: Rm. 509, Goldstein Bldg., Juneau, Alaska 99801; 323 East 4th Ave., Anchorage, Alaska 99504; University Ave., College, Alaska 99701.)

111. Foster, H. L., Analyses of stream-sediment and rock samples from the northwestern part of the Eagle quadrangle, east-central Alaska: 72 p. (incl. 65 p. tables, 2 figs.). (Wa, Da, Db, A, LA, M, S, SF; Alaska Div. Geol. Survey: Rm. 509, Goldstein Bldg., Juneau, Alaska 99801; 323 East 4 th Ave., Anchorage, Alaska 99504; University Ave., College, Alaska 99701.)

112. Foster, H. L., and Yount, M. E., Maps showing distribution of anomalous amounts of selected elements in stream-sediment and rock samples from the Eagle quadrangle, east-central Alaska: 6 p., 1 fig., 2 pls., scale 1:250,000. (Wa, Da, Db, A, LA, M, S, SF; Brooks Bldg., College, Alaska 99701; Rm. 441, Federal Bldg., Juneau, Alaska 99801; Alaska Div. Geol. Survey: Rm. 509, Goldstein Bldg., Juneau, Alaska 99801; 323 East 4th Ave., Anchorage, Alaska 99504; University Ave., College, Alaska 99701.)

113. Freiberger, H. J., and Ross, T. G., Extent and frequency of floods on Crosswicks Creek from New Egypt to Bordentown, New Jersey: 32 p., 8 figs. (Wa, Wb; Rm. 420, Federal Bldg., Trenton, N. J. 08607.)

114. Friday, John, Crest-stage gaging stations in Oregon, a compilation of peak data collected from October 1952 to September 1970: 71 p., 1 fig. (Wa, Wb, LA, M, SF; $830 \mathrm{NE.}$ Holladay St., Portland, Oreg. 97208.)

115. Frischknecht, F. C., Results of some airborne VLF surveys in northern Wisconsin: $32 \mathrm{p}$. (incl. 7 figs.), 55 pls. (Wa, Da, M; Wisconsin Geol. and Nat. History Survey, Univ. Wisconsin, 1815 University Ave., Madison, Wis. 53706.) 
116. Gann, E. E., Generalized flood-frequency estimates for urban areas in Missouri: 18 p., 3 figs. (Wa, Wb; 103 West 10th St., Rolla, Mo. 65401.)

117. Garrison, L. E., Holmes, C. W., and Trumbull, J. V. A., Geology of the insular shelf south of St. Thomas and St. John, U.S. Virgin Islands: 38 p., 9 figs., app. I-IV. (Figs. 2, 4, 7, 8, 9, and app. III and IV in pocket.) (Wa, Da, M; Univ. Corpus Christi, University Heights, Corpus Christi, Tex. 78411; Caribbean Research Inst., College Virgin Islands, St. Thomas, V. I.)

118. Gebert, W. A., Hulbert Creek hydrology, southwestern Wisconsin: 13 p., 3 figs. (Wa, Wb; Rm. 200, 1815 University Ave., Madison, Wis. 53706. )

119. Gibbs, J. F., and Eaton, J. P., A digitized map of seismic ground response of the San Francisco Bay region, California: 6 p., 1 fig., 1 table, 1 pl. (Wa, Da, La, M, SF; Library, California Div. Mines and Geology, Ferry Bldg., San Francisco, Calif. 94111; State Office Bldg., 107 South Broadway, Los Angeles, Calif. 90012.)

120. Gilbert, C. R., and Hawkinson, R. O., A proposed streamflow-data program for Texas: $52 \mathrm{p}$., 3 figs., 1 pl. (Wa, Wb, T; 630 Federal Bldg., 300 East 8 th St., Austin, Tex. 78701.)

121. Glenn, J. L., Relations among radionuclide content and physical, chemical, and mineral characteristics of Columbia River sediments, with a section by R. O. Van Atta: 157 p., 20 figs. (Wa, Wb, M, LA, SF, S; $830 \mathrm{NE}$. Holladay St., Portland, Oreg. 97208.)

122. Goddard, G. C., Jr., Jackson, N. M., Jr., Hubbard, E. F., and Hinson, H. G., A proposed streamflow-data program for North Carolina: 113 p., 1 pl., 6 figs. (Wa, Wb; 440 Century Station, Post Office Bldg., Raleigh, N. C. 27602.)

123. Gonzales, D. D., and Ducret, G. L., Jr., Rainfall-runoff investigations in the Denver metropolitan area, Colorado: 39 p., 3 figs. (Wa, Wb, Da, Db, U.)

124. Goolsby, D. A., and McPherson, B. F., Preliminary evaluation of chemical and biological characteristics of the Upper St. Johns River basin, Florida: 46 p., 5 figs. (Wa, Wb; 903 West Tennessee St., Tallahassee, Fla. 32304; Rm. 244, Federal Bldg., 207 NW. 2d St., Ocala, Fla. 32670.)
125. Grantz, Arthur, Chukchi Sea seismic reflection profiles and magnetic data, 1970, between northern Alaska and Herald Island: 32 sheets profiles, 2 sheets magnetic data, 1 location map. (Wa, Da, Db, M, A, S, SF, LA; Brooks Bldg., College, Alaska 99701; Rm. 441, Federal Bldg., Juneau, Alaska 99801; Alaska Div. Geol. Survey: Rm 509, Goldstein Bldg., Juneau, Alaska 99801; 323 East 4th Ave., Anchorage, Alaska 99504; University Ave., College, Alaska 99701.)

126. Green, M. W., Geologic map of the Continental Divide quadrangle, McKinley County, New Mexico: 18 p., 1 black-and-white map, scale 1:24,000. (Wa, Da, Db, M, U; Rm. 1 C 45, 1100 Commerce St., Dallas, Tex. 75202; Rm. 223, Geology Bldg., Univ. New Mexico, Albuquerque, N. Mex. 87106; New Mexico Bur. Mines and Mineral Resources, Socorro, N. Mex. 87801.)

127. Greenwood, W. R., Johnson, D. H., and Bahabri, M. S., A meteorite fall near Sakakah, Kingdom of Saudi Arabia: 15 p., 1 fig. (Wa, Da, M.)

128. Griffitts, W. R., Alminas, H. R., and Mosier, E. L., Beryllium distribution in the Monticello and Sierra Fijardo quadrangles, Socorro and Sierra Counties, New Mexico: 1 sheet, scale 1:24,000. (Wa, Da, Db, M, T, U; Rm. 223, Geology Bldg., Univ. New Mexico, Albuquerque, N. Mex. 87106; New Mexico Bur. Mines and Mineral Resources, Socorro, N. Mex. 87801.)

129. Griffitts, W. R., Alminas, H. V., and Moiser, E. L., Beryllium distribution in the Vicks Peak, Steel Hill, and Black Hill quadrangles, Socorro County, New Mexico: 4 sheets, scale $1: 24,000$. (Wa, Da, Db, M, T, U; Rm. 223, Geology Bldg., Univ. New Mexico, Albuquerque, N. Mex. 87106; New Mexico Bur. Mines and Mineral Resources, Socorro, N. Mex. 87801.)

130. Griffitts, W. R., Alminas, H. V., and Moiser, E. L., Lanthanum and silver distribution in the Vicks Peak, Steel Hill, and Black Hill quadrangles, Socorro County, New Mexico: 4 sheets, scale 1:24,000. (Wa, Da, Db, M, T, U; Rm. 223, Geology Bldg., Univ. New Mexico, Albuquerque, N. Mex. 87106; New Mexico Bur. Mines and Mineral Resources, Socorro, N. Mex. 87801.)

131. Griffitts, W. R., Alminas, H. V., and Mosier, E. L., Lead distribution in the Monticello and Sierra Fijardo quadrangles, Socorro and Sierra 
Counties, New Mexico: 1 sheet, scale 1:24,000. (Wa, Da, Db, M, T, U; Rm. 223, Geology Bldg., Univ. New Mexico, Albuquerque, N. Mex. 87106; New Mexico Bur. Mines and Mineral Resources, Socorro, N. Mex. 87801.)

132. Griffitts, W. R., Alminas, H. V., and Mosier, E. L., Lead distribution in the Vicks Peak, Steel Hill, and Black Hill quadrangles, Socorro County, New Mexico: 4 sheets, scale 1:24,000. (Wa, Da, Db, M, T, U; Rm. 223, Geology Bldg., Univ. New Mexico, Albuquerque, N. Mex. 87106; New Mexico Bur. Mines and Mineral Resources, Socorro, N. Mex. 87801.)

133. Griffitts, W. R., Alminas, H. V., and Moiser, E. L., Molybdenum distribution in the Vicks Peak, Steel Hill, and Black Hill quadrangles, Socorro County, New Mexico: 4 sheets, scale 1:24,000. (Wa, Da, Db, M, T, U; Rm. 223, Geology Bldg., Univ. New Mexico, Albuquerque, N. Mex. 87106; New Mexico Bur. Mines and Mineral Resources, Socorro, N. Mex. 87801.)

134. Griffitts, W. R., Alminas, H. V., and Mosier, E. L., Niobium and gold distribution in the Vicks Peak, Steel Hill, and Black Hill quadrangles, Socorro County, New Mexico: 4 sheets, scale 1:24,000. (Wa, Da, Db, M, T, U; Rm. 223, Geology Bldg., Univ. New Mexico, Albuquerque, N. Mex. 87106; New Mexico Bur. Mines and Mineral Resources, Socorro, N. Mex. 87801.)

135. Griffitts, W. R., Alminas, H. V., and Mosier, E. L., Strontium distribution in the Vicks Peak, Steel Hill, and Black Hill quadrangles, Socorro County, New Mexico: 4 sheets, scale 1:24,000. (Wa, Da, Db, M, T, U; Rm. 223, Geology Bldg., Univ. New Mexico, Albuquerque, N. Mex. 87106; New Mexico Bur. Mines and Mineral Resources, Socorro, N. Mex. 87801.)

136. Griffitts, W. R., Alminas, H. V., and Mosier, E. L., Tin distribution in the Vicks Peak, Steel Hill, and Black Hill quadrangles, Socorro County, New Mexico: 4 sheets, scale 1:24,000. (Wa, Da, Db, M, T, U; Rm. 223, Geology Bldg., Univ. New Mexico, Albuquerque, N. Mex. 87106; New Mexico Bur. Mines and Mineral Resources, Socorro, N. Mex. 87801.)

137. Griffitts, W. R., Alminas, H. V., and Mosier, E. L., Zinc and antimony distribution in the Vicks Peak, Steel Hill, and Black Hill quadrangles, Socorro County, New Mexico: 4 sheets, scale 1:24,000. (Wa, Da, Db, M, T, U; Rm. 223, Geology Bldg., Univ. New Mexico, Albuquerque, N. Mex. 87106; New Mexico Bur. Mines and Mineral Resources, Socorro, N. Mex. 87801.)

138. Grossling, B. F., and Ericksen, G. E., Computer studies of the composition of Chilean nitrate ores: data reduction, basic statistics and correlation analysis: 85 p., 8 figs., 18 tables. (Wa, Da, M.)

139. Gunard, K. T., and Guetzkow, L. C., Small-stream flood investigations in Minnesota, October 1958 to September 1969: 174 p., 16 figs. (Wa, Wb; Rm. 1033, Post Office Bldg., St. Paul, Minn. 55101.)

140. Hackman, R. J., and Williams, P. L., Geologic evaluation of 3-5 micrometer infrared imagery and color photography in southern Utah: 43 p., 9 figs., 1 table. (Wa, Da, F, M.)

141. Hail, W. J., Jr., Geologic reconnaissance map of the Bear Mountain and Oakbrush Ridge quadrangles, Hinsdale and Archuleta Counties, Colorado: 1 sheet, scale 1:48,000. (Wa, Da, Db, M, U; Colorado Geol. Survey, Rm. 254, Columbine Bldg., 1845 Sherman St., Denver, Colo. 80203.)

142. Hail, W. J., Jr., Geologic reconnaissance map of the Chris Mountain and Pagosa Springs quadrangles, Archuleta County, Colorado: 1 sheet, scale 1:48,000. (Wa, Da, Db, M, U; Colorado Geol. Survey, Rm. 254, Columbine Bldg., 1845 Sherman St., Denver, Colo. 80203.)

143. Hail, W. J., Jr., Barnes Harley, and Zapp, A. D., Geologic reconnaissance map of the Rules $\mathrm{Hill}$ and Ludwig Mountain quadrangles, La Plata County, Colorado: 1 sheet, scale 1:48,000. (Wa, Da, Db, M, U; Colorado Geol. Survey, Rm. 254, Columbine Bldg., 1845 Sherman St., Denver, Colo. 80203.)

144. Hampton, B. B., and Myers, D. R., Annual compilation and analysis of hydrologic data for Pin Oak Creek, Trinity River basin, Texas, 1969: 28 p., 2 figs. (Wa, Wb, T; Rm. 630, Federal Bldg., 300 East 8 th St., Austin, Tex. 78701.)

145. Hardt, W. F., and "Cordes, E. H., Analysis of ground-water system in Orange County, California, by use of an electrical analog 
model: 60 p., 24 figs. (Wa, Wb, M, SF, LA; 855 Oak Grove Ave., Menlo Park, Calif. 94025.)

146. Hauth, L. D., and Spencer, D. W., Floods in Coldwater Creek, Watkins Creek, and River Des Peres basins, St. Louis County, Missouri: 21 p., 25 figs. (Wa, Wb; 103 West 10th St., PO Box 340, Rolla, Mo. 65401.)

147. Hawkins, D. B., and Forbes, R. B., Investigation of gold mineralization along a part of the Elliott Highway, Fairbanks district, Alaska: 65 p., 3 figs., 1 pl. (Wa, Da, Db, A, LA, M, S, SF; Brooks Bldg., College, Alaska 99701; Rm. 441, Federal Bldg., Juneau, Alaska 99801; Alaska Div. Geol. Survey: Rm. 509, Goldstein Bldg., Juneau, Alaska 99801; 323 East 4th Ave., Anchorage, Alaska 99504; and University Ave., College, Alaska 99701.)

148. Hejl, H. R., Jr., Annual compilation and analysis of hydrologic data for Deep Creek, Colorado River basin, Texas, 1969: 73 p., 2 figs. (Wa, $\mathrm{Wb}, \mathrm{T}$; Rm. 630, Federal Bldg., 300 East 8th St., Austin, Tex. 78701.)

149. Hejl, H. R., Jr., Annual compilation and analysis of hydrologic data for Mukewater Creek, Colorado River basin, Texas, 1969: 84 p., 2 figs. (Wa, Wb, T; Rm. 630, Federal Bldg., 300 East 8th St., Austin, Tex. 78701.)

150. Helley, E. J., and Brabb, E. E., Geologic map of Late Cenozoic deposits, Santa Clara County, California: $1 \mathrm{map}$, index map, explanation (3 sheets) scale 1:52,500. (Wa, Da, M, SF; LA; Library, California Div. Mines and Geology, Ferry Bldg., San Francisco, Calif. 94111; State Office Bldg., 107 South Broadway, Los Angeles, Calif. 90012.)

151. Hladio, Stephen, Poultney River near Hampton, New York: Floodflow characteristics at bridge site: $14 \mathrm{p}$. (Wa, Wb; 343 U.S. Post Office and Court House, Albany, N.Y. 12201.)

152. Hodges, C. A., Preliminary study of Hycon photographs, Apollo 14:5 p., 3 figs. (Wa, Da, F, M.)

153. Hubbell, D. W., and Glenn, J. L., Distribution of radionuclides in bottom sediments of the Columbia River estuary: 152 p., 33 figs: (Wa, Wb, LA, M, S, SF; 830 NE. Holladay St., Portland, Oreg. 97208.)

154. Huber, N. K., The Keweenawan geology of Isle Royale, Michigan: 9 p., plus 6 figs. (Wa, $\mathrm{Da}$, M.)
155. Hull, J. E., Hydrologic conditions during 1969 in Dade County, Florida: 37 p., 39 figs. (Wa, Wb; 903 West Tennessee St., Tallahassee, Fla. 32304.)

156. Janda, R. J., Preliminary report on coastal terraces and estimated rates of erosion and soil formation, Coos and Curry Counties, Oregon: 6 p., 2 figs. (Wa, Wb, M, SF, S; 830 NE. Holladay St., Portland, Oreg. 97208.)

157. Jenkins, E. D., Test of the Stroebel Spring, a supplementary study of the Fort Carson Expansion Project, Civil Action No. 9820, Tract No. 202, El Paso County, Colorado: 20 p., 3 figs. (Wa, Wb, Db, U; PO Box 3267, 19th and Iowa Sts., Lawrence, Kans. 66044.)

158. Johnson, C. W., Bowden, L. W., and Pease, R. W., A system of regional agricultural land use mapping tested against small scale Apollo 9 color infrared photography of the Imperial Valley (California): 97 p., 10 figs., 8 tables. (Wa, Da, F, M.)

159. Johnson, G. R., Preliminary results of induced polarization-resistivity surveys in the Northgate district, Colorado: 18 p., 7 figs. (Wa, Da, Db, M, U; Colorado Geol. Survey, Rm. 254, Columbine Bldg., 1845 Sherman St., Denver, Colo. 80203.)

160. Johnson, L. E., Continuing sediment investigations in Indiana by the U.S. Geological Survey-A progress report: 28 p., 4 figs. (Wa, Wb; 1819 North Meridian St., Indianapolis, Ind. 46202.)

161. Johnson, M. V., and Omang, R. J., Annual peak discharges from small drainage areas in Montana through September 1970: 138 p., 1 fig. (Wa, Wb, Db, S, U; Rm. 421, Federal Bldg., Helena, Mont. 59601.)

162. Johnson, S. L., Urban hydrology of the Houston, Texas metropolitan area, compilation of basic data, 1968: 302 p., 14 figs. (Wa, Wb, T; Rm. 630, Federal Bldg., 300 East 8th St., Austin, Tex. 78701.)

163. Jordan, D. G., Water and copper-mine tailings in karst terrane of Rio Tanama basin, Puerto Rico: 24 p., 12 figs. (Wa, Wb; Bldg. 652, Fort Buchanan, P. R. 00934.)

164. Kachadoorian, Reuben, Preliminary engineering geologic maps of the proposed trans-Alaska pipeline route, Bettles and Beaver quadrangles: 2 sheets ( 2 maps, explanation, scale $1: 125,000$ ). (Wa, Da, Db, A, LA, M, S, SF; Brooks Bldg., College, Alaska 99701; Rm. 
441, Federal Bldg., Juneau, Alaska 99801; Alaska Div. Geol. Survey: Rm. 509, Goldstein Bldg., Juneau, Alaska 99801; 323 East 4th Ave., Anchorage, Alaska 99504; University Ave., College, Alaska 99701.)

165. Kachadoorian, Reuben, Preliminary engineering geologic maps of the proposed trans-Alaska pipeline route, Livengood and Tanana quadrangles: 2 sheets ( 2 maps, explanation, scale 1:125,000). (Wa, Da, Db, A, LA, M, S, SF; Brooks Bldg., College, Alaska 99701; Rm. 441, Federal Bldg., Juneau, Alaska 99801; Alaska Div. Geol. Survey: Rm. 509, Goldstein Bldg., Juneau, Alaska 99801; 323 East 4th Ave., Anchorage, Alaska 99504; University Ave., College, Alaska 99701.)

166. Kachadoorian, Reuben, Preliminary engineering geologic maps of the proposed trans-Alaska pipeline route, Wiseman and Chandalar quadrangles: 2 sheets ( 2 maps, explanation, scale 1:125,000). (Wa, Da, Db, A, LA, M, S, SF; Brooks Bldg., College, Alaska 99701; Rm. 441, Federal Bldg., Juneau, Alaska 99801; Alaska Div. Geol. Survey: Rm. 509, Goldstein Bldg., Juneau, Alaska 99801; 323 East 4th Ave., Anchorage, Alaska 99504; University Ave., College, Alaska 99701.)

167. Kantrowitz, I. H., and Johnston, R. H., A summary of geologic and hydrologic data from an exploratory well drilled near Greenwood, Delaware: 19 p., 4 figs. (Wa, Wb, 8809 Satyr Hill Rd., Parkville, Md. 21 234.)

168. Kantrowitz, I. H., and Webb, W. E., Geologic and hydrologic data from a test well drilled near Chestertown, Maryland: 21 p., 4 figs. (Wa, Wb; 8809 Satyr Hill Rd., Parkville, Md. 21234.)

169. Karlstrom, T. N. V., Preliminary geologic map of the Schickard quadrangle of the Moon: map and explanation ( 1 sheet), scale 1:1,000,000. (Wa, Da, F, M.)

170. Kidwell, C. C., Annual compilation and analysis of hydrologic data for North Creek, Trinity River basin, Texas, 1969: 32 p., 2 figs. (Wa, Wb, T; Rm. 630, Federal Bldg., 300 East 8th St., Austin, Tex. 78701.)

171. Kinney, D. M., Preliminary geologic map of southwest third of Kings Canyon quadrangle, North Park, Jackson County, Colorado: 1 sheet, scale 1:48,000. (Wa, Da, Db, M, U; Colorado Geol. Survey, Rm. 254, Columbine Bldg., 1845 Sherman St., Denver, Colo. 80203.)
172. Koehler, J. H., Ground-water conditions during 1969, Vandenberg Air Force Base area, California: 37 p., 6 figs. (Wa, Wb, LA, M, SF; 855 Oak Grove Ave., Menlo Park, Calif. 94025.)

173. Koopman, F. C., Open-channel integrating-type flow meter: 25 p., 5 figs. (Wa, Wb, Db, T; PO Box 4369, Albuquerque, N. Mex. 87106.)

174. Kosanke, R. M., Palynological investigations in the Pennsylvanian of Kentucky, VI: $20 \mathrm{p}$. (Wa, Da, M; 710 West High St., Lexington, Ky. 40508; Kentucky Geol. Survey, Rm. 307, Mineral Industries Bldg., Univ. Kentucky, Lexington, Ky. 40506.)

175. Krinsley, D. B., Davies, W. E., Rachlin, J., and Newton, E. G., Existing environment of natural corridors from Prudhoe Bay, Alaska, to Edmonton, Canada: 104 p., 1 pl. (Wa, Da, Db, M, A, SF, LA, S; Brooks Bldg., College, Alaska 99701; Rm. 441, Federal Bldg., Juneau, Alaska 99801; Alaska Div. Geol. Survey: Rm. 509, Goldstein Bldg., Juneau, Alaska 99801; 323 East 4th Ave., Anchorage, Alaska 99504; University Ave., College, Alaska 99701.)

176. Krushensky, R. D., Hornblende-plagioclase porphyry intrusives in the northeast quarter of the Ponce quadrangle, Puerto Rico: 2 p., 1 map, explanation. (Wa, Da, M; Lamar St. and Franklin Roosevelt Ave., San Juan, P. R. 00963.)

177. Lamonds, A. G., Hydrologic data for Horseshoe Lake, Arkansas, and vicinity: $36 \mathrm{p} ., 1 \mathrm{pl}$. (Wa, Wb, T; 2301 Federal Office Bldg., 700 West Capitol Ave., Little Rock, Ark. 72201.

178. Landis, E. R., and Cone, G. C., Coal reserves of Colorado tabulated by bed: 3 p., 515 tables. (Wa, Da, Db, M; Colorado Geol. Survey, Rm. 254, Columbine Bldg., 1845 Sherman St., Denver, Colo. 80203.)

179. Laney, R. L., Weathering of the granodioritic rocks in the Rose Canyon Lake area, Santa Catalina Mountains, Arizona: 201 p., 44 figs. (Wa, Wb, Db, LA, SF, U; 2555 East 1st St., Tucson, Ariz. 85717; Rm. 5017, Federal Bldg., 230 North 1st Ave., Phoenix, Ariz. 85025.)

180. LaSala, A. M., Jr., and Doty, G. C., Preliminary evaluation of hydrologic factors related to radioactive waste storage in basaltic rocks at 
Hanford Reservation, Washington: 80 p., 10 figs. (Wa, Wb, LA, M, S, SF; Rm. 289, Federal Bldg., Richland, Wash. 99352.)

181. Laughlin, C. P., and Hughes, D. M., Hydrologic records for Volusia County, Florida, 1970-71: 14 p., 31 figs. (Wa, Wb; 903 West Tennessee St., Tallahassee, Fla. 32304.)

182. Livingston, R. K., Evaluation of streamflow-data program in Colorado: 76 p., 3 figs. (Wa, Wb, Da, Db.)

183. Lofgren, B. E., Estimated subsidence in the Chino-Riverside and Bunker Hill-Yucaipa areas in southern California for a postulated water-level lowering, 1965 to 2015: 20 p., 5 figs. (Wa, Wb, LA, M, SF; Rm. 2235, Federal Bldg., 2800 Cottage Way, Sacramento, Calif. 95825; 855 Oak Grove Ave., Menlo Park, Calif. 94025.)

184. Lofgren, B. E., Estimated subsidence in the Raymond Basin, Los Angeles County, California, for a postulated water-level lowering, 1970-2020: 23 p., 6 figs. (Wa, Wb, M, SF, LA; Rm. W-2528, Federal Bldg., 2800 Cottage Way, Sacramento, Calif. 95825; 855 Oak Grove Ave., Menlo Park, Calif. 94025.)

185. Lowham, H. W., Wilson, J. F., Jr., Preliminary results of time-of-travel measurements on Wind/Bighorn River from Boysen Dam to Greybull, Wyoming: 7 p., 1 fig. (Wa, Wb, Db, U; 1214 Big Horn Ave., Worland, Wyo. 82401; 215 East 8th Ave., Cheyenne, Wyo. 82001.)

186. McAllister, J. F., Preliminary geologic map of the Amargosa Valley borate area, Inyo County, California: 1 sheet, scale 1:24,000. (Wa, Da, LA, M, SF; Library, California Div. Mines and Geology, Ferry Bldg., San Francisco, Calif. 94111; State Office Bldg., 107 South Broadway, Los Angeles, Calif. 90012.)

187. McAllister, J. F., Preliminary geologic map of the Funeral Mountains in the Ryan quadrangle, Death Valley region, Inyo County, California: 1 sheet, scale $1: 31,680$. (Wa, Da, LA, M, SF, Library, California Div. Mines and Geol., Ferry Bldg., San Francisco, Calif. 94111; State Office Bldg., 107 South Broadway, Los Angeles, Calif. 90012.)

188. McAvoy, R. L., U.S. Geological Survey Central Laboratory in Salt Lake City, Utah: 4 p. (Wa, Wb, U.)
189. McCauley, J. F., and Wilhelms, D. E., Geologic provinces of the near side of the Moon: 5 p., 1 fig. (Wa, Da, F, M.)

190. McConaghy, J. A., and Bowman, W. N., Water resources of the Juneau area, Alaska: 82 p., 23 figs. (Wa, Wb, M, A, LA, SF, S; Skyline Bldg., 218 E St., Anchorage, Alaska 99501; Rm. 441, Federal Bldg., 710 West 9th St., Juneau, Alaska 99801.)

191. McCord, J. R., Review and analysis of Apollo 14 master positives: 6 p., 5 figs., 1 table. (Wa, Da, F, M.)

192. McCulloch, D. S., Conomos, T. J., Peterson, D. H., and Leong, K., Distribution of mercury in surface sediments in San Francisco Bay estuary, California: map and explanation (1 sheet). (Wa, Da, LA, M, SF; Library, California Div. Mines and Geology, Ferry Bldg., San Francisco, Calif. 94111; State Office Bldg., 107 South Broadway, Los Angeles, Calif. 90012.)

193. McGreevy, L. J., and Bjorklund, L. J., Geohydrologic sections, Cache Valley, Utah and Idaho: 6 p. (Wa, Wb, SF, U.)

194. Mack, F. K., Progress report on the analog model study of the Magothy aquifer in the Annapolis, Maryland area: 26 p. 5 figs. (Wa, Wb; 8809 Satyr Hill Rd., Parkville, Md. 21234.)

195. MacKevett, E. M., Jr., Analyses of samples and preliminary geologic summary of barite-silver-base metal deposits near Glacier Creek, Skagway B-4 quadrangle, southeastern Alaska: 8 p., 2 figs., 1 table. (Wa, Da, Db, M, A, SF, LA, S; Brooks Bldg., College, Alaska 99701; Rm. 441, Federal Bldg., Juneau, Alaska 99801; Alaska Div. Geol. Survey: Rm. 509, Goldstein Bldg., Juneau, Alaska 99801; 323 East 4th Ave., Anchorage, Alaska 99504; University Ave., College, Alaska 99701.)

196. McLaughlin, R. J., Geology of the Sargent fault zone in the vicinity of Mount Madonna, Santa Clara County, California: 1 map with explanation and cross sections ( 3 sheets), scale 1:12,000. (Wa, Da, LA, M, SF; Library, California Div. Mines and Geology: Ferry Bldg., San Francisco, Calif. 94111; State Office Bldg., 107 South Broadway, Los Angeles, Calif. 90012.) 
197. Maclay, R. W., Winter, T. C., and Bidwell, L. E., Water resources of the Red River of the North drainage basin in Minnesota: 309 p., 58 figs. (Wa, Wb; Rm. 1033, Post Office Bldg., St. Paul, Minn. 55101.)

198. McLean, J. S., The microclimate in Carlsbad Caverns, New Mexico: 67 p., 19 figs. (Wa, Wb, Db, T; Rm. 223, Geology Bldg., Univ. New Mexico, Albuquerque, N. Mex. 87106.)

199. McPherson, B. F., Hydrobiological characteristics of Shark River estuary, Everglades National Park, Florida: 113 p., 19 figs. (Wa, Wb; 903 West Tennessee St., Tallahassee, Fla. 32304; 730 Federal Bldg., 51 SW. 1st Ave., Miami, Fla. 33130.)

200. McPherson, B. F., Water quality of the Dade-Collier Training and Transition Airport, Miami International Airport, and Cottonmouth Camp-Everglades National Park, Florida, November 1969: 29 p., 2 figs. (Wa, Wb; 903 West Tennessee St., Tallahassee, Fla. 32304; Rm. 730, Federal Bldg., 51 SW. 1st Ave., Miami, Fla. 33130.)

201. Massey, B. C., Annual compilation and analysis of hydrologic data for Green Creek, Brazos River basin, Texas, 1969: 44 p., 2 figs. (Wa, Wb, Da, T; Rm. 630, Federal Bldg., 300 East 8 th St., Austin, Tex. 78701.)

202. Matson, N. A., Jr., and Richter, D. H., Geochemical data from the Nabesna A-1 quadrangle, Alaska: 10 p., 1 fig. (Wa, Da, Db, A, LA, M, S, SF; Brooks Bldg., College, Alaska 99701; Rm. 441, Federal Bldg., Juneau, Alaska 99801; Alaska Div. Geol. Survey: Rm. 509, Goldstein Bldg., Juneau, Alaska 99801; 323 East 4th Ave., Anchorage, Alaska 99504; University Ave., College, Alaska 99701.)

203. Matson, N. A., Jr., and Richter, D. H., Geochemical data from the Nabesna C-4 quadrangle, Alaska: 6 p., 1 fig. (Wa, Da, Db, A, LA, M, S, SF; Brooks Bldg., College, Alaska 99701; Rm. 441, Federal Bldg., Juneau, Alaska 99801; Alaska Div. Geol. Survey: Rm. 509, Goldstein Bldg., Juneau, Alaska 99801; 323 East 4th Ave., Anchorage, Alaska 99504; University Ave., College, Alaska 99701.)

204. Matson, N. A., Jr., and Richter, D. H., Geochemical data from the Nabesna C-5 quadrangle, Alaska: 10 p., 1 fig. ( $\mathrm{Wa}, \mathrm{Da}, \mathrm{Db}$, A, LA, M, S, SF; Brooks Bldg., College,
Alaska 99701; Rm. 441, Federal Bldg., Juneau, Alaska 99801; Alaska Div. Geol. Survey: Rm. 509, Goldstein Bldg., Juneau, Alaska 99801; 323 East 4th Ave., Anchorage, Alaska 99504; University Ave., College, Alaska 99701.)

205. Matson, N. A., Jr., and Richter, D. H., Geochemical data from the Nabesna D-5 quadrangle, Alaska: 8 p., 1 fig. (Wa, Da, Db, A, LA, M, S, SF; Brooks Bldg., College, Alaska 99701; Rm. 441, Federal Bldg., Juneau, Alaska 99801; Alaska Div. Geol. Survey: Rm. 509, Goldstein Bldg., Juneau, Alaska 99801; 323 East 4th Ave., Anchorage, Alaska 99504; University Ave., College, Alaska 99701.)

206. Mercer, J. W., and Lappala, E. G., Drilling and testing of well 69, Fort Wingate Army Depot, McKinley County, New Mexico: 41 p., 7 figs. (Wa, Wb, Db, T; Rm. 223, Geology Bldg., Univ. New Mexico, Albuquerque, N. Mex. 87106.)

207. Meyer, F. W., Preliminary evaluation of the hydrologic effects of implementing water and sewerage plans, Dade County, Florida: 103 p., 20 figs. (Wa, Wb; 903 West Tennessee St., Tallahassee, Fla. 32304; Rm. 730, Federal Bldg., 51 SW. 1st Ave., Miami, Fla. 33130.)

208. Miller, E. M., Virginia small streams program-preliminary flood-frequency relations: 28 p., 13 figs. (Wa, Wb; 200 West Grace St., Rm. 304, Richmond, Va. 23220.)

209. Miller, R. E., and Singer, J. A., Subsidence in the Bunker Hill-San Timoteo area, southern California: 27 p., 17 figs. (Wa, Wb, LA, M, SF; 855 Oak Grove Ave., Menlo Park, Calif. 94025.)

210. Miller, T. P., Petrology of the plutonic rocks of west-central Alaska: $136 \mathrm{p}$. (incl. 32 figs., 12 tables), 5 pls. (Wa, Da, Db, A, LA, M, S, SF; Brooks Bldg., College, Alaska 99701; Rm. 441, Federal Bldg., Juneau, Alaska 99801; Alaska Div. Geol. Survey: Rm. 509, Goldstein Bldg., Juneau, Alaska 99801; 323 East 4th Ave., Anchorage, Alaska 99504; University Ave., College, Alaska 99701.)

211. Miller, T. P., Elliott, R. L., Grybeck, D. H., and Hudson, T. L., Results of geochemical sampling in the northern Darby Mountains, Seward.Peninsula, Alaska: 12 p. (incl. 1 fig., 1 table). (Wa, Da, Db, A, LA, M, S, SF; Brooks Bldg., College, Alaska 99701; Rm. 
441, Federal Bldg., Juneau, Alaska 99801; Alaska Div. Geol. Survey: Rm. 509, Goldstein Bldg., Juneau, Alaska 99801; 323 East 4th Ave., Anchorage, Alaska 99504; University Ave., College, Alaska 99701.)

212. Mudge, M. R., Earhart, R. L., Watts, K. C., Jr., Tuchek, E. T., and Rice, W. L., Mineral Resources of the Lincoln Back Country area, Powell and Lewis and Clark Counties, Montana, with a section on Geophysical surveys, by D. L. Peterson: 326 p., (incl. 160 p. tables, 5 pls. 19 figs., 8 photographs). (Wa, Da, Db, M, U; Montana Bur. Mines and Geology, Montana College Mineral Sci. and Technology, Butte, Mont. 59701; U.S. Bur. Mines, West 222 Mission, Spokane, Wash. 99201.)

213. Muffler, L. J. P., Evaluation of inital investigations, Dieng geothermal area, central Java, Indonesia: 21 p., 1 fig., 1 table. (Wa, $\mathrm{Da}, \mathrm{M}$.)

214. Mycyk, R. T., and Grant, R. S., Floods in Harvard southwest quadrangle, northeastern Illinois: 13 p., 10 figs., 1 pl. (Wa, Wb; PO Box 1026, 605 North Neil St., Champaign, Ill. 61820.)

215. Nelson, L. M., Sediment transport by streams in the Snohomish River basin, Washington, October 1967-June 1968: 96 p., 28 figs. (Wa, Wb, LA, M, S, SF; Rm. 300, 1305 Tacoma Ave., South, Tacoma, Wash. 98402.)

216. Nichols, D. R., and Wright, N. A., Preliminary map of historic margins of marshland, San Francisco Bay, California: 11 p., 1 map, scale $1: 125,000$. (Wa, Da, LA, M, SF; Library, California Div. Mines and Geology, Ferry Bldg., San Francisco, Calif. 94111; State Office Bldg., 107 South Broadway, Los Angeles, Calif. 90012.)

217. Nilsen, T. H., and Brabb, E. E., Preliminary photointerpretation and damage maps of landslide and other surficial deposits in northeastern San Jose, California: Map, explanation ( 1 sheet), scale $1: 24,000$. (Wa, Da, M, SF, LA; Library, California Div. Mines and Geology, Ferry Bldg., San Francisco, Calif. 94111; State Office Bldg., 107 South Broadway, Los Angeles, Calif. 90012.)

218. Nunnally, N. R., and Witmer, R. E., A land use interpretation experiment, TR 69-5: $22 \mathrm{p}$., 4 figs., 1 table. (Wa, Da, F, M.)
219. Offield, T. W., and Karlstrom, T. N. V., Traverse map of the Fra Mauro landing site: 1 sheet, scale 1:5,000. (Wa, Da, Db, A, F, LA, M, S, SF, T, U.)

220. Oldale, R. N., Uchupi, Elazar, and Prada, K. E., Western Gulf of Maine and the southeastern Massachusetts offshore area: sedimentary framework: 37 p. (incl. 1 fig.), 7 sheets. (Wa, Da, M; 80 Broad St., Boston, Mass. 02110; Albatross St., Woods Hole, Mass. 02543.)

221. Overstreet, W. C., Monazite in Taiwan: 80 p., 1 fig., 7 tables. (Wa, Da, M.)

222. Overstreet, W. C., White, A. M., Theobald, P. K., Jr., and Caldwell, D. W., Selected fluvial monazite deposits in the Southeastern United States: 108 p., 4 pls., 1 fig., 17 tables. (Wa, $\mathrm{Da}, \mathrm{M}$.

223. Page, R. W., Base of fresh ground-water approximately 3000 micromhos, in the San Joaquin Valley, California: 13 p., 1 pl. (Wa, Wb, M, SF, LA; 855 Oak Grove Ave., Menlo Park, Calif. 94025.)

224. Patton, W. W., Jr., and Csejtey, Béla, Jr., Preliminary geologic investigations of eastern St. Lawrence Island, Alaska: $52 \mathrm{p}$. (incl. 41 p., tables, 4 figs.) (Wa, Da, Db, A, LA, M, S, SF; Brooks Bldg., College, Alaska 99701; Rm. 441, Federal Bldg., Juneau, Alaska 99801; Alaska Div. Geol. Survey: Rm. 509, Goldstein Bldg., Juneau, Alaska 99801; 323 East 4th Ave., Anchorage, Alaska 99504; University Ave., College, Alaska 99701.)

225. Pease, R. W., Alexander, R. H., and Pease, S. R., Mapping terrestrial radiation emission with the RS-14 scanner: 27 p., 12 figs. (Wa, $\mathrm{Da}, \mathrm{F}$, M.)

226. Pitt, A. M., Microearthquake activity in the vicinity of Wooded Island, Hanford region, Washington: 24 p., 7 figs., 2 tables. (Wa, Da, M.)

227. Pollock, S. J., Salt contamination of the water supply at Auburn, Massachusetts: 13 p., 1 fig. (Wa, Wb; Rm. 2300, John F. Kennedy Federal Bldg., Boston, Mass. 02203.)

228. Powell, J. E., and Jorgensen, D. G., Approximate optimum yield of the glacial outwash aquifer between Sioux Falls and Dell Rapids, South Dakota: 9 p., 1 fig. (Wa, Wb; Rm. 231, Federal Bldg., Huron, S. Dak. 75350.) 
229. Powers, W. R., III, and Irwin, G. A., Water-resources inventory, spring 1969 to spring 1970, Antelope Valley-East Kern Water Agency area, California: 19 p., 10 figs. (Wa, Wb, M, SF, LA; 855 Oak Grove Ave., Menlo Park, Calif. 94025.)

230. Rabon, J. W., A proposed streamflow-data program for Florida: 64 p., 2 figs. (Wa, Wb; 903 West Tennessee St., Tallahassee, Fla. 32304.)

231. Radbruch, D. H., and Wentworth, C. M., Estimated relative abundance of landslides in the San Francisco Bay region, California: map and explanation, scale 1:500,000, text (total-1 sheet). (Wa, Da, LA, M, SF; Library, California Div. Mines and Geology, Ferry Bldg., San Francisco, Calif. 94111; State Office Bldg., 107 South Broadway, Los Angeles, Calif. 90012.)

232. Reddy, D. R., Annual compilation and analysis of hydrologic data for Escondido Creek, San Antonio River basin, Texas, 1969: 62 p., 2 figs. (Wa, Wb, Da, T; Rm. 630, Federal Bldg., 300 East 8th St., Austin, Tex. 78701.)

233. Reed, J. C., Jr., and Love, J. D., Preliminary geologic map of the Mount Bannon quadrangle, Teton County, Wyoming: 1 sheet, scale 1:24,000. (Wa, Da, Db, M, U; Geol. Survey Wyoming, Univ. Wyoming, Laramie, Wyo. 82070.)

234. Reed, L. A., Effects of roadway and pond construction on sediment yield near Harrisburg, Pennsylvania: 26 p., 7 figs. (Wa, Wb; 228 Walnut St., Harrisburg, Pa. 17108.)

235. Reeder, H. E., Sedimentation in Third Creek Subwatershed No. 7A, North Carolina: 31 p., 3 figs. (Wa, Wb; 300 Fayetteville St., Raleigh, N. C. 27602.)

236, Reiland, L. J., Depletions, losses, and gains along the Pecos River from Alamogordo Dam to Acme gage, New Mexico: 110 p., 23 figs. (Wa, $\mathrm{Wb}, \mathrm{Db}, \mathrm{T} ; \mathrm{Rm} .223$, Geology Bldg., Univ. New Mexico, Albuquerque, N. Mex. 87106.)

237. Reiser, H. N., Brosgé, W. P., Dutro, J. T., Jr., and Detterman, R. L., Preliminary geologic map, Mt. Michelson quadrangle, Alaska: map, explanation (2 sheets), scale $1: 200,000$. (Wa, $\mathrm{Da}, \mathrm{Db}, \mathrm{A}, \mathrm{LA}, \mathrm{M}, \mathrm{S}$, SF; Brooks Bldg., College, Alaska 99701; Rm. 441, Federal Bldg., Juneau, Alaska 99801; Alaska Div. Geol. Survey: Rm. 509, Goldstein Bldg.,
Juneau, Alaska 99801; 323 East 4th Ave., Anchorage, Alaska 99504, University Ave., College, Alaska 99701.)

238. Renner, J. L., Lithologic units useful for solar evaporation pond construction at Searles Lake, San Bernardino County, California: 6 p., 1 fig., 1 pl. (map at scale 1:62,500). (Wa, Da, M, SF, LA, U.)

239. Rickher, J. G., and others, Water records of Puerto Rico, 1964-67, vol. 1: 265 p., 9 maps. (Wa, Wb; Bldg. 652, Fort Buchanan, P. R. 00934.)

240. Robbins, W. D., Annual compilation and analysis of hydrologic data for urban studies in the Austin, Texas, metropolitan area, 1969: 46 p., 3 figs. (Wa, Wb, T; Rm. 630, Federal Bldg., 300 East 8th St., Austin, Tex. 78701.)

241. Robertson, A. F., A preliminary evaluation of hydrologic conditions in the Lakeland Ridge area of Polk County, Florida: 48 p., 8 figs. (Wa, Wb; 903 West Tennessee St., Tallahassee, Fla. 32304; Rm. 437, Federal Bldg., 500 Zack St., Tampa, Fla. 33602.)

242. Rossman, D. L., Ahmad, Zaki, and Rahman, Hamidur, Geology and ecomomic potential for chromite in the Zhob Valley ultramafic rock complex, Hindubagh, Quetta Division, West Pakistan: 63 p., 13 figs. (Wa, Da, M.)

243. Sansom, J. N., Annual compilation and analysis of hydrologic data for Cow Bayou, Brazos River basin, Texas, 1969: 76 p., 3 figs. (Wa, Wb, T; Rm. 630, Federal Bldg., 300 East 8th St., Austin, Tex. 78701.)

244. Sansom, J. N., Annual compilation and analysis of hydrologic data for Elm Fork Trinity River, Trinity River basin, Texas, 1969; 47 p., 2 figs. (Wa, Wb, T; Rm. 630, Federal Bldg., 300 East 8th St., Austin, Tex. 78701.)

245. Santos, E. S., and Moench, R. H., Measured sections of the Morrison Formation and related rocks in northwestern New Mexico: $61 \mathrm{p} ., 1$ fig., 1 table. (Wa, $\mathrm{Da}, \mathrm{Db}, \mathrm{M}, \mathrm{U}, \mathrm{T}$; Rm. 223, Geology Bldg., Univ. New Mexico, Albuquerque, N. Mex. 87106; New Mexico State Bur. Mines and Mineral Resources, Socorro, N. Mex. 87801.)

246. Schlocker, J., Generalized geologic materials of the San Francisco Bay region: map, explanation, text (1 sheet), scale 1:500,000. (Wa, Da, LA, M, SF; Library, California Div. 
Mines and Geology, Ferry Bldg., San Francisco, Calif. 94111; State Office Bldg., 107 South Broadway, Los Angeles, Calif. 90012.)

247. Schmoll, H. R., and Dobrovolny, Ernest, Generalized slope map of the Eagle River-Birchwood area, greater Anchorage area, Borough, Alaska: 1 sheet, scale $1: 63,360$. (Wa, Da, Db, M, A, SF, LA, S; Brooks Bldg., College, Alaska 99701; Rm. 441, Federal Bldg., Juneau, Alaska 99801; Alaska Div. Geol. Survey: Rm. 509, Goldstein Bldg., Juneau, Alaska 99801; 323 East 4th Ave., Anchorage, Alaska 99504; University Ave., College, Alaska 99701.)

248. Schmoll, H. R., Dobrovolny, Ernest, and Zenone, Chester, Generalized geologic map of the Eagle River-Birchwood area, greater Anchorage area, Borough, Alaska: 1 sheet, scale 1:63,360. (Wa, Da, Db, M, A, SF, LA, S; Brooks Bldg., College, Alaska 99701; Rm. 441, Federal Bldg., Juneau, Alaska 99801; Alaska Div. Geol. Survey: Rm. 509, Goldstein Bldg., Juneau, Alaska 99801; 323 East 4th Ave., Anchorage, Alaska 99504; University Ave., College, Alaska 99701.)

249. Schroeder, E. E., Flood stages and discharges for small streams in Texas: 319 p., 6 figs. (Wa, Wb, Da, T; Rm. 630, Federal Bldg., 300 East 8th St., Austin, Tex. 78701.)

250. Schroeder, M. L., Preliminary geologic map of the Clause Peak quadrangle, Lincoln, Sublette, and Teton Counties, Wyoming: Map with cross sections and table of chemical analyses of phosphatic rock (1 sheet), scale 1:24,000. (Wa, Da, Db, M, U.)

251. Scott, A. G., Preliminary flood-frequency relations and summary of maximum dischartes in New Mexico-A progress report: 76 p., 8 figs. (Wa, Wb, Db, T; Rm. 223, Geology Bldg., Univ. New Mexico, Albuquerque, N. Mex. 87106.)

252. Scott, G. R., Preliminary map of landslide deposits in the Green Mountain area, Jefferson County, Colorado: 3 p., 1 sheet, scale 1:24,000. (Wa, $\mathrm{Da}, \mathrm{Db}, \mathrm{M}, \mathrm{U}$.)

253. Shaffer, F. B., Characteristics of streamflow at gaging stations in Shell Creek, Elkhorn River, and Salt Creek basin, Nebraska: 73 p., 10 figs. (Wa, Wb; Rm. 127, Nebraska Hall, 901 North 17th St., Lincoln, Nebr. 68508.)
254. Sharp, R. V., Meidav, Tsvi, and Sigurdson, D. R., Seismic profiles of Salton Sea, southern California-Cruise of August 1969: 2 maps and explanation (1 sheet), 7 rolls sparker records. (M, LA.)

255. Shattles, D. E., Quality of surface water in the Pat Harrison Waterway District, Mississippi, 1970 water year: 58 p., 1 fig. (Wa, Wb; 430 Bounds St., Jackson, Miss. 39206.)

256. Sheridan, D. M., and Reed, J. C., Jr., Preliminary geologic map of the Bergen Park area, Jefferson and Clear Creek Counties, Colorado: map and explanation (1 sheet), scale 1:24,000. (Wa, Da, Db, M, U.)

257. Sheth, Madhusudan, A heavy mineral study of Pleistocene and Holocene sediments near Nome, Alaska: 83 p., (incl. 25 figs.). (Wa, Da, Db, A, LA, M, S, SF; Brooks Bldg., College, Alaska 99701; Rm. 441, Federal Bldg., Juneau, Alaska 99801; Alaska Div. Geol. Survey: Rm. 509, Goldstein Bldg., Juneau, Alaska 99801; 323 East 4th Ave., Anchorage, Alaska 99504; University Ave., College, Alaska 99701.)

258. Silvey, W. D., Concentration of minor elements in California streams, 1960-69: 37 p. (Wa, Wb, M, SF, LA; 855 Oak Grove Ave., Menlo Park, Calif. 94025.)

259. Simmons, G. C., Geologic map of the Ishpeming quadrangle, Marquette County, Michigan: 1 sheet, scale 1:12,000. (Wa, Da, M; Michigan Dept. of Natural Resources, Geol. Survey Div., Stevens T. Mason Bldg., Lansing, Mich. 48926.)

260. Simonett, D. S., and Brooner, W. G., Crop type discrimination with color infrared photography: preliminary results in Douglas County, Kansas: 7 p., 1 fig., 1 table. (Wa, Da, F, M.)

261. Simonett, D. S., Henderson, F. M., and Egbert, D. D., On the use of space photography for identifying transportation routes: a summary of problems: 23 p., 9 figs., 9 tables. (Wa, Da, F, M.)

262. Simons, F. S., Geologic map of the Lochiel quadrangle, Santa Cruz County, Arizona: 5 sheets, scale 1:48,000. (Wa, Da, Db, LA, M, $\mathrm{SF}, \mathrm{U}$; Arizona Bur. Mines, Univ. Arizona, Tucson, Ariz. 85721.) 
263. Simons, F. S., Geologic map of the Nogales quadrangle, Santa Cruz County, Arizona: 6 sheets, scale 1:48,000. (Wa, Da, Db, LA, M, $\mathrm{SF}, \mathrm{U}$; Arizona Bur. Mines, Univ. Arizona, Tucson, Ariz. 85721.)

264. Skipp, Betty and McMannis, W. J., Geologic map of the Sedan quadrangle, Gallatin and Park Counties, Montana: map and explanation (2 sheets), scale 1:48,000. (Wa, Da, Db, M, S, U; Idaho Bur. Mines and Geology, Univ. Idaho, Moscow, Idaho 83843; Montana Bur. Mines and Geology, Montana College Min. Sci. and Technology, Butte, Mont. 59701.)

265. Slack, K. V., and others, Selected procedures for biological and microbiological investigations: 68 p. (Wa, Wb, M.)

266. Sniegocki, R. T., and Bedinger, M. S., A plan for water-resources investigations in Arkansas, with definitions of hydrologic units: $70 \mathrm{p}$., 8 figs. (Wa, Wb, T; Rm. 2301, Federal Office Bldg., 700 West Capitol Ave., Little Rock, Ark. 72201.)

267. Staatz, M. H., Geologic map of the Hall Mountain area in Copeland quadrangle, Boundary County, Idaho: map (2 sheets), scale $1: 24,000$. (Wa, Da, M, S, U.)

268. Steele, T. D., A study of the chemical quality of streamflow in Arkansas: 96 p., 8 figs. (Wa, Wb, T; Rm. 2301, Federal Office Bldg., 700 West Capitol St., Little Rock, Ark. 72201.)

269. Stone, B. D., Deglaciation events in part of the Manchester South $7.5^{\prime}$ quadrangle, south-central New Hampshire: 84 p., 2 pls., 16 figs. (Wa; 80 Broad St., Boston, Mass. 02110; New Hampshire Dept. Resources and Econ. Devel., State House Annex, Concord, N. H. 03301.)

270. Sullavan, J. N., Thermal survey of Dardanelle Reservoir: 31 p., 1 fig. (Wa, Wb, T; Rm. 2301, Federal Office Bldg., 700 West Capitol St., Little Rock, Ark. 72201.)

271. Sumsion, C. T., Water-resources investigations in Dinosaur National Monument, Utah-Colorado, fiscal year 1970: 52 p., 13 figs. (Wa, Wb, Db; Rm. 8002, Federal Bldg., 125 South State St., Salt Lake City, Utah 84111.)

272. Sutton, R. L., Batson, R. M., Larson, K. B., Schafer, J. P., Eggleton, R. E., and Swann, G. A., Documentation of the Apollo 14 samples: 37 p. (incl. 31 figs.). (Wa, Da, F, M.)
273. Sutton, R. L., Hait, M. H., Wolfe, E. W., Batson, R. M., Bailey, N. G., Freeman, V. L., Larson, K. B., Muehlberger, W. R., Reed, V. S., Schaber, G. G., Swann, G. A., Tyner, R. L., Ulrich, G. E., and Wilshire, H. G., Preliminary documentation of the Apollo 15 samples: 153 p., 55 figs., 5 tables. (Wa, $\mathrm{Da}, \mathrm{Db}, \mathrm{M}, \mathrm{A}$, SF, LA, S, U.)

274. Swann, G. A., and others, Preliminary geologic investigations of the Apollo 14 landing site: 124 p., 60 figs., 4 tables. (Wa, $\mathrm{Da}, \mathrm{F}, \mathrm{M}$.)

275. Swift, C. H., III, Appraisal of streamflow in Tualatin River basin, Washington County, Oregon: 68 p., 14 figs. (Wa, Wb, LA, M, SF, $S ; 830$ NE. Holladay St., Portland, Oreg. 97208.)

276. Tailleur, I. L., Translation of 1964 Russian correlations between Wrangel Island and northern Alaska: 13 p., 2 figs. (Wa, $\mathrm{Da}, \mathrm{Db}$, A, LA, M, S, SF; Brooks Bldg., College, Alaska 99701; Rm. 441, Federal Bldg., Juneau, Alaska 99801; Alaska Div. Geol. Survey: Rm. 509, Goldstein Bldg., Juneau, Alaska 99801; 323 East 4th Ave., Anchorage, Alaska 99504; University Ave., College, Alaska 99701.)

277. Tanner, A. B., Linear combination reading program for capture gamma rays: 9 p. (Wa.)

278. Taylor, O. J., Preliminary digital model studies of the Rio Aconcagua Valley, Chile: $37 \mathrm{p}$., 8 figs. (Wa, Wb.)

279. Terman, M. J., Environments at U.S. and U.S.S.R. nuclear explosion sites: petroleum-stimulation projects: $62 \mathrm{p}$., 25 figs., 8 tables. (Wa, Da, M.)

280. Theobald, P. K., and Thompson, C. E., Geochemical maps of Samrah and vicinity, Kingdom of Saudi Arabia: 9 p., 8 figs. (Wa, $\mathrm{Da}, \mathrm{M}$.

281. Theobald, P. K., Jr., Al Kushaymiyah as a target for a Colorado-type molybdenite deposit: 13 p., 3 pls., 2 figs. (Wa, Da, M.)

282. Theodore, T. G., Geologic map of the Copper Canyon area, Battle Mountain mining district, Lander County, Nevada: Map and explanation (2 sheets), scale 1:4,800. (Wa, Da, M, SF, LA, U; Library, Mackay School Mines, Univ. Nevada, Reno, Nev. 89507.)

283. Thompson, Woodrow, The drainage and glacial history of the Still River Valley, southwestern 
Connecticut: 55 p., 12 figs., 1 map, scale 1:24,000. (Wa; 80 Broad St., Boston, Mass. 02110; Connecticut Geol. and Nat. History Survey, Wesleyan Univ., Middletown, Conn. 06457.)

284. Tourtelot, H. A., and Tailleur, I. L., The Shublik Formation and adjacent strata in northwestern Alaska: 62 p., 1 fig., 1 table. (Wa, Da, Db, A, LA, M, S, SF; Brooks Bldg., College, Alaska 99701; Rm. 441, Federal Bldg., Juneau, Alaska 99801; Alaska Div. Geol. Survey: Rm. 509, Goldstein Bldg., Juneau, Alaska 99801; 323 East 4th Ave., Anchorage, Alaska 99504; University Ave., College, Alaska 99701.)

285. Truesdell, A. H., Geochemical evaluation of the Dieng Mountains, central Java, for the production of geothermal energy: 14 p., 4 figs., 7 tables. (Wa, Da, M.)

286. Tweto, Ogden, Geologic map of the Holy Cross quadrangle, Eagle, Lake, Pitkin, and Summit Counties, Colorado: map, explanation (2 sheets), scale 1:24,000. (Wa, Da, Db, M, U; Colorado Geol. Survey, Rm. 254, Columbine Bldg., 1845 Sherman St., Denver, Colo. 80203.)

287. Tyley, S. J., Analog model study of the ground-water basin of the upper Coachella Valley, California: 89 p., 38 figs. (Wa, Wb, LA, M, SF; 855 Oak Grove Ave., Menlo Park, Calif. 94025; 13245 Harbor Blvd., Garden Grove, Calif. 92643.)

288. U.S. Geological Survey, Aeromagnetic map of part of south-central New Mexico: 1 sheet, scale 1:62,500. (Wa, Da, Db, M, T, U; Rm. 223, Geology Bldg., Univ. New Mexico, Albuquerque, N. Mex. 87106; New Mexico State Bur. Mines and Mineral Resources, Campus Station, Socorro, N. Mex. 87801.)

289. U.S. Geological Survey, Aeromagnetic map of part of west-central Utah: 1 sheet, scale 1:250,000. (Wa, Da, Db, M, U; Idaho Bur. Mines and Geology, Moscow, Idaho 83843; Montana Bur. Mines and Geology, Montana College Mineral Sci. and Technology, Butte, Mont. 59701; Utah Geol. and Mineralog. Survey, Rm. 103, Utah Geol. Survey Bldg., Univ. Utah, Salt Lake City, Utah 84111.)

290. U.S. Geological Survey, Aeromagnetic map of southwestern Idaho: 1 sheet, scale 1:500,000. (Wa, Db, M, S, U; Idaho Bur. Mines and Geology, Moscow, Idaho 83843.)
291. U.S. Geological Survey, Aeromagnetic map of the Challis, May, Lone Pine Peak, and Doublespring quadrangles, east-central Idaho: scale 1:62,500. (Wa, Da, Db, M, S, U; Idaho Bur. Mines and Geology, Univ. Idaho, Moscow, Idaho 83843.)

292. U.S. Geological Survey, Aeromagnetic map of the Custer, Elevenmile Creek, Sunbeam, Thompson Creek, and Clayton quadrangles, east-central Idaho: 1 sheet, scale 1:62,500. (Wa, Da, Db, M, S, U; Idaho Bur. Mines and Geology, Univ. Idaho, Moscow, Idaho 83843.)

293. U.S. Geological Survey, Aeromagnetic map of the Patterson and Leodore quadrangles, east-central Idaho: 1 sheet, scale 1:62,500. (Wa, Da, Db, M, S, U; Idaho Bur. Mines and Geology, Univ. Idaho, Moscow, Idaho 83843.)

294. U.S. Geological Survey, Aeromagnetic map of the southern part of the San Francisco Bay region, California: 1 sheet, scale $1: 125,000$. (Wa, Da, M, SF, LA; Library, California Div. Mines and Geology, Ferry Bldg., San Francisco, Calif. 94111; State Office Bldg., 107 South Broadway, Los Angeles, Calif. 90012.)

295. U.S. Geological Survey, Aeromagnetic map of the Stillwater complex and vicinity, south-central Montana: 2 sheets, scale 1:62,500. (Wa, Da, $\mathrm{Db}, \mathrm{M}, \mathrm{S}$, U; Montana Bur. Mines and Geology, Montana College of Mineral Sci. and Technology, Butte, Mont. 59701.)

296. U.S. Geological Survey, An evaluation of ground-water conditions in the vicinity of the Bel Bay development, Lummi Indian Reservation, Washington: 25 p., 2 figs. (Wa, Wb, M, SF, LA, S; Rm. 300, 1305 Tacoma Ave., South, Tacoma, Wash. 98402.)

297. U.S. Geological Survey, Apollo 14 traverse map: 1 sheet, scale 1:2,500. (Wa, Da, F, M.)

298. U.S. Geological Survey, Chemical quality of water in southeastern Wyoming: 67 p., 1 fig. (Wa, Wb, Db, U; 215 East 8th Ave., Cheyenne, Wyo. 82201.)

299. U.S. Geological Survey, Compilation of hydrologic data, Calaveras Creek, San Antonio River basin, Texas, 1968: 66 p., 2 figs. (Wa, Wb, T; Rm. 630, Federal Bldg., 300 East 8th St., Austin, Tex. 78701.) 
300. U.S. Geological Survey, Compilation of hydrologic data, Deep Creek, Colorado River basin, Texas, 1968: 86 p., 2 figs. (Wa, Wb, T; Rm. 630, Federal Bldg., 300 East 8th St., Austin, Tex. 78701.)

301. U.S. Geological Survey, Compilation of hydrologic data, Green Creek, Brazos River basin, Texas, 1968: 66 p., 2 figs. (Wa, Wb, T; Rm. 630, Federal Bldg., 300 East 8th St., Austin Tex. 78701.)

302. U.S. Geological Survey, Compilation of hydrologic data, Honey Creek, Trinity River basin, Texas, 1968: 78 p., 2 figs. (Wa, Wb, T; Rm. 630, Federal Bldg., 300 East 8th St., Austin Tex. 78701.)

303. U.S. Geological Survey, Compilation of hydrologic data, Pin Oak Creek, Trinity River basin, Texas, 1968: 44 p., 2 figs. (Wa, Wb, T; Rm. 630, Federal Bldg., 300 East 8th St., Austin Tex. 78701.)

304. U.S. Geological Survey, Hadley-Apennine site shaded relief map: 1 sheet, scale 1:12,500. (Wa, Da, F, M.)

305. U.S. Geological Survey, Preliminary report on the geology and field petrology at the Apollo 15 landing site: 15 p., 6 figs., 4 tables. (Wa, $\mathrm{Da}$, $\mathrm{Db}, \mathrm{A}, \mathrm{F}, \mathrm{LA}, \mathrm{M}, \mathrm{S}, \mathrm{SF}, \mathrm{T}, \mathrm{U}$.)

306. U.S. Geological Survey, Side looking radar mosaic (APS-94D), Connecticut and Rhode Island, with parts of adjacent states-uncontrolled (south looking); uncontrolled (north looking): 2 sheets (mosaics), scale 1:500,000. (Wa, Da, M; 80 Broad St., Boston, Mass. 02110; Connecticut Geol. and Nat. History Survey, Wesleyan Univ., Middletown, Conn. 06457.)

307. U.S. Geological Survey, Surface operational maps of the Apennine-Hadley landing site-Apollo 15: 2 sheets, scales $1: 25,000$ and 1:12,500. (Wa, Da, F, M.)

308. U.S. Geological Survey, the U.S. Bureau of Land Management, and the U.S. Bureau of Mines, Base maps of areas underlain by Green River Formation in the eastern part of the Uinta Basin, Utah and Colorado, the southern part of the Green River Basin, Wyoming and Utah, and the Piceance Creek Basin, Colorado: 3 sheets, scale $1: 250,000$. (Wa, Db, U.)

309. Vedder, J. G., Dibblee, T. W., Jr. and Brown, R. D., Jr., Geologic map of the upper Mono Creek-Pine Mountain area, California, showing rock units and structures offset by the Big Pine Fault: 1 sheet, scale 1:48,000. (Wa, Da, M, LA, SF; Library, California Div. Mines and Geology, Ferry Bldg., San Francisco, Calif. 94111; State Office Bldg., 107 South Broadway, Los Angeles, Calif. 90012.)

310. Venkatarathnam, K., Heavy minerals on the continental shelf of the northern Bering Sea: 93 p., 57 figs. (Wa, Da, Db, A, LA, M, S, SF; Brooks Bldg., College, Alaska 99701; Rm. 441, Federal Bldg., Juneau, Alaska 99801; Alaska Div. Geol. Survey: Rm. 509, Goldstein Bldg., Juneau, Alaska 99801; 323 East 4th Ave., Anchorage, Alaska 99504; University Ave., College, Alaska 99701.)

311. Voegeli, P. T., Sr., Hydraulic testing and sampling of water well 1 , Project Wagon Wheel, Sublette County, Wyoming: 26 p., 7 Figs. (Wa, Wb, Db; Office of Coordinator, AEC Hydrology Project, Bldg. 25, Denver Federal Center, Denver, Colo. 80225.)

312. Voegeli, P. T., Sr., and Claassen, H. C., $R$ adiochemical analyses of water from selected streams, wells, springs, and precipitation collected prior to reentry drilling, Project Rulison: 15 p., 1 fig. (Wa, Wb, Db; AEC Hydrology Projects Office, Bldg., 25, Denver Federal Center, Denver, Colo. 80225.)

313. Waananen, A. O., Floods from small drainage areas in California-A compilation of peak data, October 1958 to September 1970: 134 p., 27 figs. (Wa, Wb, M, SF, LA; 855 Oak Grove Ave., Menlo Park Calif. 94025.)

314. Wallace, J. C., An inventory of medium-sized lakes in California, 1970: 7 p., 1 fig. (Wa, Wb, LA, M, SF; 855 Oak Grove Ave., Menlo Park, Calif. 94025.)

315. Water Resources Division, Index of surface water stations in Texas, October 1971: 28 p., 1 fig. (Wa, Wb, Db, U; 215 East 8th Ave., Cheyenne, Wyo. 82001; 1214 Big Horn Ave., Worland, Wyo. 82401.)

316. Webber, E. E., and Mayo, R. I., Low-flow study for southwest Ohio streams: 20 p., 1 fig. (Wa, Wb; 975 West 3d Ave., Columbus, Ohio 43212.)

317. Weber, F. R., Preliminary engineering geologic maps of the proposed trans-Alaska pipeline route, Fairbanks and Big Delta quadrangles: 2 sheets ( 2 maps, explanation, scale 1:125,000). (Wa, Da, Db, A, LA, M, S, SF; Brooks Bldg., 
College, Alaska 99701; Rm. 441, Federal Bldg., Juneau, Alaska 99801; Alaska Div. Geol. Survey: Rm. 509, Goldstein Bldg., Juneau, Alaska 99801; 323 East 4th Ave., Anchorage, Alaska 99504; University Ave., College, Alaska 99701.)

318. Weber, F. R., Preliminary engineering geologic maps of the proposed trans-Alaska pipeline route, Mount Hayes quadrangle: 2 sheets 2 maps, explanation, scale $1: 125,000$ ). (Wa, Da, Db, A, M, LA, S, SF; Brooks Bldg., College, Alaska 99701; Rm. 441, Federal Bldg., Juneau, Alaska 99801; Alaska Div. Geol. Survey: Rm. 509, Goldstein Bldg., Juneau, Alaska 99801; 323 East 4th Ave., Anchorage, Alaska 99504; University Ave., College, Alaska 99701.)

319. Weis, Paul, and Tuchek, E. T., Mineral resources of ten areas proposed as additions to the Eagle Cap Wilderness, Oregon: 52 p., 2 pl., 10 figs., 3 tables (one table is $112 \mathrm{p}$. long). (Wa, Da, M, SF, LA, S; Oregon Dept. Geology and Mineral Industries, Rm. 1069, State Office Bldg., 1400 SW. 5th Ave., Portland, Oreg. 97201; U.S. Bur. Mines, West 222 Mission St., Spokane, Wash. 99201.)

320. Welder, F. A., Ground-water reconnaissance of selected sites in Rocky Mountain National Park and Shadow Mountain National Recreation area, Colorado: 16 p., 3 figs. (Wa, $\mathrm{Wb}, \mathrm{Da}, \mathrm{Db}$.)

321. Welder, G. E., Map showing the altitude and configuration of the water level in the "shallow aquifer," January 1969, Roswell basin, Chaves and Eddy Counties, New Mexico: 1 map. (Wa, Wb, Db, T; PO Box 4369, Albuquerque, N. Mex. 87106.)

322. Whitaker, G. L., A proposed streamflow-data program for Utah: 46 p., 4 figs. (Wa, Wb, U.)

323. Whitlow, J. W., Areas in the southern Najd quadrangle, Saudi Arabia, recommended for mineral investigations: 11 p., 2 figs. (Wa, Da, M.)

324. Whitlow, J. W., Map showing approximate top of Jacobsville sandstone, an erosion surface, in parts of Rockland and Greenland quadrangles, Ontonagon County, Michigan: map and explanation ( 1 sheet), scale $1: 62,500$. (Wa, Da, M; Michigan Dept. Nat. Resources, Geol. Survey Div., Stevens T. Mason Bldg., Lansing, Mich. 48926.)
325. Wibben, H. C., Peak stages and discharges on small streams in Tennessee, 1965-71: $52 \mathrm{p}$., 1 fig. (Wa, Wb; Rm. 144, Federal Office Bldg., Nashville, Tenn, 37203.)

326. Wilhelms, D. E., and Davis, D. E., Two former faces of the Moon: 5 p., 3 figs. (Wa, Da, F, M.)

327. Williams, G. P., Aids in designing laboratory flumes: 194 p., 69 figs. (Wa, Wb.)

328. Winkler, G. R., Mackevett, E. M., Jr., and Smith, J. G., Geochemical reconnaissance of the McCarthy B-6 quadrangle, Alaska: 8 p. (incl. 4 tables; 1 pl.), scale $1: 63,360$. (Wa, Da, Db, A, LA, M, S, SF; Brooks Bldg., College, Alaska 99701; Rm. 441, Federal Bldg., Juneau, Alaska 99801; Alaska Div. Geol. Survey: Rm. 509, Goldstein Bldg., Juneau, Alaska 99801; 323 East 4th Ave., Anchorace, Alaska 99504; University Ave., College, Alaska 99701.)

329. Witmer, R. E., Tellico test site land use map: 6 p., 1 fig., 8 maps. (Wa, Da, F, M.)

330. Wotorson, C. S., and Behrendt, J. C., Aeromagnetic map of the Juarzoa quadrangle, Liberia: 2 sheets, 5 p., scale 1:250,000. (Wa, Da, M.)

331. Wotorson, C. S., and Behrendt, J. C., Aeromagnetic map of the Zwedru quadrangle, Liberia: 2 sheets, 5 p., scale 1:250,000. (Wa, Da, M.)

332. Wotorson, C. S., and Behrendt, J. C., Total-count gamma radiation map of the Zwedru quadrangle, Liberia: 1 map (2 sheets), scale $1: 250,000,5$ p. (Copy at scale of $1: 125,000$ included.) (Wa, Da, M.)

333. Wright, J. C., and Finch, W. I., An annotated bibliography of fauna and flora described from the Dockum Group of Triassic age in eastern New Mexico and west Texas: 26 p. (Wa, Da, Db, T, U; Bur. Econ. Geology, Univ. Texas, Austin, Tex. 78712.)

334. Wrucke, C. T., and Armbrustmacher, T. J., Preliminary geologic map of the Tenabo area, Shoshone Range, Lander County, Nevada: map and explanation (1 sheet), scale 1:15,840. (Wa, Da, LA, SF, U; Library, Mackay School Mines, Univ. Nevada, Reno, Nev. 89507. ) 
335. Yerkes, R. F., Campbell, R. H., Blackerby, B. A., Wentworth, C. M., Birkeland, P. W., and Schoellhamer, J. E., Preliminary geologic map of the Malibu Beach quadrangle, Los Angeles County, California: map with explanation and cross sections ( 2 sheets), scale $1: 12,000$. (Wa, Da, M, SF, LA; Library, California Div. Mines and Geology, Ferry Bldg., San Francisco, Calif. 94111; State Office Bldg., 107 South Broadway, Los Angeles, Calif. 90012.)
336. Yotsukura, Nobuhiro, Cory, R. L., and Murakami, Ken, A tracer simulation of waste transport in the Muddy Creek-Rhode River estuary, Maryland: 28 p., 6 figs. (Wa, Wb.)

337. Zohdy, A. A. R., Hershey, L. A., Emery, P. A., and Stanley, W. D., Resistivity sections, upper Arkansas River basin, Colorado: 21 p., 1 fig. (Wa, Wb, Da, Db, U.) 


\section{INDEX}

A

Report

Alaska, analyses and geologic summary, barite-silverbase metal deposits, Skagway B-4

quadrangle ..................... 195

bedrock geologic map, Wiseman and Survey

Pass quadrangles ................ 56

Bouguer anomaly maps, Seward Peninsula and

Yukon Flats ...................... 14

coal resources, Cape Beaufort coal field $\ldots \ldots \ldots \ldots \ldots 61$

correlation of Paleozoic structure of Wrangel

Island with western Brooks Range ......... 276

Cretaceous plutonic rocks, St. Lawrence

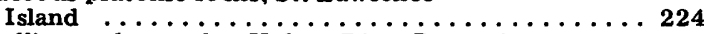

crystalline rock samples, Yukon River-Porcupine

River area, magnetic susceptibilities $\ldots \ldots \ldots \ldots \ldots \mathbf{5 5}$

early Paleozoic fossils, Neruokpuk Formation .......99

engineering geologic maps, Beechey Point and Sagavanirktok quadrangles, proposed

pipeline route $\ldots \ldots \ldots \ldots \ldots \ldots \ldots$

Bettles and Beaver quadrangles, proposed

Fairbanks and Big Deita quadrangles,

proposed pipeline route $\ldots \ldots \ldots \ldots \ldots \ldots \ldots 317$

Gulkana quadrangle, proposed pipeline

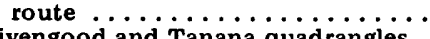

Livengood and Tanana quadrangles, proposed pipeline route .............. 165

Mount Hayes quadrangle, proposed pipeline route $\ldots \ldots \ldots \ldots \ldots$

Philip Smith Mountains quadrangle, proposed pipeline route $\ldots \ldots \ldots$

Valdez quadrangle, proposed pipeline

Wiseman and Chandalar quadrangles, proposed

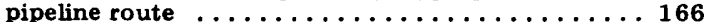

geochemical data, Nabesna A-1 quadrangle ....... 202

Nabesna $C-4$ quadrangle $\ldots \ldots \ldots \ldots \ldots \ldots \ldots \ldots 20 . \ldots \ldots$

Nabesna C-5 quadrangle $\ldots \ldots \ldots \ldots \ldots \ldots \ldots \ldots 204$

Nabesna D-5 quadrangle . . . . . . . . . . . . . . 205

geochemical reconnaissance, McCarthy B-6 quadrangle $\ldots \ldots \ldots \ldots \ldots \ldots \ldots \ldots \ldots \ldots \ldots \ldots$

geochemical sampling, Seward Peninsula, northern

Darby Mountains $\ldots . . \ldots \ldots \ldots 211$

geologic investigations, eastern $\mathrm{St}$. Lawrence

Island $\ldots \ldots \ldots \ldots \ldots \ldots \ldots \ldots \ldots \ldots \ldots \ldots .6 \ldots \ldots$

geologic map, Anchorage $\mathrm{B}-6$ quadrangle $\ldots \ldots \ldots \ldots \ldots 70$

Eagle River-Birchwood area $\ldots \ldots \ldots \ldots \ldots \ldots \ldots 248$

Livengood quadrangle $\ldots \ldots \ldots \ldots \ldots \ldots \ldots \ldots \ldots 66$

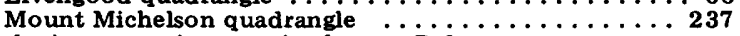

geologic reconnaissance, Anchorage B-6

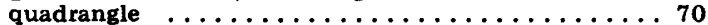

Anchorage B-7 quadrangle $\ldots \ldots \ldots \ldots \ldots \ldots \ldots \ldots 71$

geology, Cape Beaufort coal field $\ldots \ldots \ldots \ldots \ldots \ldots 61$

Forrester Island National Wildlife

Refuge $\ldots \ldots \ldots \ldots \ldots \ldots \ldots \ldots \ldots \ldots$

geology and geochemistry, Sinuk River, Seward Peninsula $\ldots \ldots \ldots \ldots \ldots \ldots \ldots \ldots$

gold mineralization, Fairbanks district. investigation $\ldots \ldots \ldots \ldots \ldots \ldots \ldots \ldots \ldots \ldots \ldots$

gravity maps, Seward Peninsula and Yukon Flats $\ldots \ldots \ldots \ldots \ldots \ldots \ldots \ldots \ldots \ldots \ldots \ldots$

ground-water exploration, Beaver Creek

Valley .....................6

lake-level fluctuations, Kenai-Soldotna area $\ldots \ldots \ldots \ldots \ldots 7$ magnetic data, Chukchi Sea $\ldots \ldots \ldots \ldots \ldots \ldots \ldots 125$ metallic mineral resources map, Mount McKinley quadrangle $\ldots \ldots \ldots \ldots \ldots \ldots \ldots 72$

Pennsylvanian carbonates, eastern Brooks Range, paleoecology and stratigraphy $\ldots \ldots \ldots \ldots \ldots \ldots \ldots$
Alaska--Continued

Pleistocene and Holocene sediments, near

Nome, heavy minerals ................ 257

Prudhoe Bay to Edmonton, Canada, environment .... 175

seismic reflection profiles, Chukchi Sea $\ldots \ldots \ldots \ldots 125$

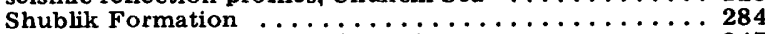

slope map, Eagle River-Birchwood area ......... 247

stream-sediment and rock analyses, Anchorage

B-6 quadrangle ................. 70

Anchorage B-7 quadrangle, geochemical ........71

Eagle quadrangle . ...............110, 111

anomalous distribution of elements $\ldots \ldots \ldots \ldots 112$

stream-sediment samples, Taylor Mountains D-8

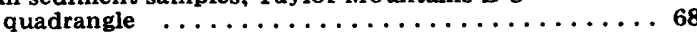

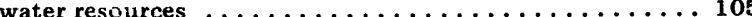

Juneau area . . . . . . . . . . . . . . . . 190

west-central, petrology, plutonic rocks $\ldots \ldots \ldots \ldots \ldots 210$

Antimony, New Mexico, Socorro County, distribution $\ldots 137$

Apollo 9, infrared color photography, land use

mapping ..................... 158

Apollo 14 , Hy con photographs, preliminary study $\ldots \ldots \ldots 152$

landing site, geologic investigations $\ldots \ldots \ldots \ldots \ldots \ldots 274$

lunar-surface pictures $\ldots \ldots \ldots \ldots \ldots \ldots \ldots \ldots 17$

review and analysis $\ldots \ldots \ldots \ldots \ldots \ldots 19 \ldots \ldots \ldots 1$

sample documentation $\ldots \ldots \ldots \ldots \ldots \ldots \ldots \ldots \ldots 272$

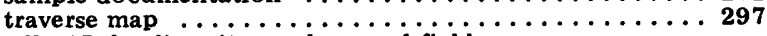

Apollo 15, landing site, geology and field petrology, preliminary report $\ldots \ldots \ldots \ldots \ldots \ldots 305$

landing site, relief map $\ldots \ldots \ldots \ldots \ldots \ldots \ldots \ldots \ldots$

samples, preliminary documentation $\ldots \ldots \ldots \ldots \ldots 273$

surface operational maps $\ldots \ldots \ldots \ldots \ldots \ldots \ldots \ldots .307$

pictures, preliminary catalog $\ldots \ldots \ldots \ldots \ldots \ldots \ldots \ldots$

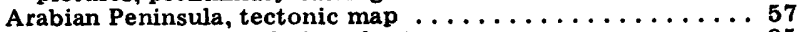

Arctic Mesozoic correlation chart $\ldots \ldots \ldots \ldots \ldots \ldots \ldots$

Arizona, geologic map, Pima County, Empire Mountains area .................. 106

geologic map, Santa Cruz County, Lochiel

quadrangle $\ldots \ldots \ldots \ldots \ldots \ldots \ldots \ldots \ldots \ldots 262$

Santa Cruz County, Nogales quadrangle .........263 granodiorite rocks, Rose Canyon Lake area, weathering $\ldots \ldots \ldots \ldots \ldots \ldots \ldots \ldots \ldots$

Arkansas, Dardanella Reservoir, thermal survey $\ldots \ldots \ldots 270$ hydrologic data, Horseshoe Lake $\ldots \ldots \ldots \ldots \ldots \ldots \ldots \ldots$ streamflow, quality ................ 268

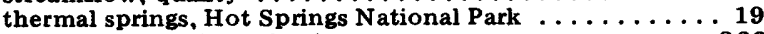
water-resources investigations $\ldots \ldots \ldots \ldots \ldots \ldots \ldots \ldots \ldots \ldots \ldots$

Barite deposits, Alaska, Skagway B-4 quadrangle, analyses and geologic summary .......... 195

Base metal deposits, Alaska, Skagway B-4 quadrangle, analyses and geologic summary .......... 195

Bering Sea, northern, heavy minerals on continental shelf .....................310

Beryllium, New Mexico, Socorro County, distribution ... 129

New Mexico, Socorro and Sierra Counties, distribution .................. 128

Biological and microbiological investigations, selected procedures

California, aeromagnetic map, San Francisco Bay region $\ldots \ldots \ldots \ldots \ldots \ldots \ldots \ldots \ldots \ldots \ldots$ from

channel capacity, Fresn Hidden Damsite, Madera County ..........41

Madera County, reach of Chowchilla River .......40 Ash and Berenda Sloughs $\ldots \ldots \ldots \ldots \ldots \ldots \ldots .40$ 
California--Continued

floods from small drainage areas, peak-data compilation, 1958-70 .................313

fresh ground water, $S a n$ Joaquin Valley $\ldots \ldots \ldots \ldots \ldots 223$

geologic map, Contra Costa, Alameda, and San Joaquin Counties, Mount DiabloByron area $\ldots \ldots \ldots \ldots \ldots \ldots \ldots$

Funeral Mountains, Inyo County, Ryan quadrangle $\ldots \ldots \ldots \ldots \ldots \ldots \ldots \ldots \ldots \ldots$

Inyo County, Amargosa valley borate area .......... 186

Los Angeles County, Malibu Beach quadrangle . . . . 335

Santa Clara County, Late Cenozoic deposits . . . . 150

Sonoma and Marin Counties .............44

upper Mono Creek-Pine Mountain area ...............

geologic maps, along San Andreas fault, vicinity of King City, Coalinga, Panoche Valley, and Paso Robles .............. 87

geologic materials, San Francisco Bay region .......246

geology, Santa Clara County, Sargent fault

zone ....................... 196

ground water, Dos Palos-Kettleman City area,

chemical quality .................. 39

Orange County, electrical analog model ......... 145

ground-water basin, upper Coachella Valley, analog model study $\ldots \ldots \ldots \ldots \ldots \ldots \ldots . \ldots 287$ ground-water conditions, 1969 , Vandenberg $\mathrm{Air}$

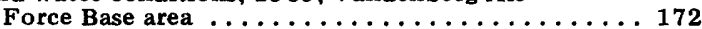

lakes, medium-sized, inventory $\ldots \ldots \ldots \ldots \ldots \ldots \ldots . \ldots \ldots 14$

landslide and other surficial deposits, north-

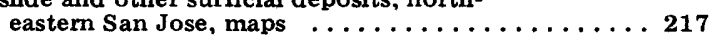

landslides, $\mathbf{S}$ an Francisco Bay region $\ldots \ldots \ldots \ldots \ldots 231$

marshland, San Francisco Bay, historic margins . . . . 216 mercury in surface sediments, San Francisco

Bay estuary $\ldots \ldots \ldots \ldots \ldots \ldots \ldots$
San Andreas and related faults, Los Angeles,

San Bernardino, and Riverside Counties .......88

seismic ground response, San Francisco Bay

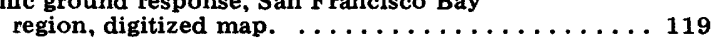

seismic profiles, Salton Sea . . . . . . . . . . . 254

solar evaporation pond construction, San Bernardino County, Searles Lake ......... 238

streamflow-data program, proposed $\ldots \ldots \ldots \ldots \ldots \ldots .80$

streams, Colorado Desert subregion, temperatures $\ldots \ldots$ 45

minor elements . ..................... 258

north coastal subregion, temperatures . . . . . . 46

Sacramento basin, temperatures $\ldots \ldots \ldots \ldots \ldots \ldots \ldots 47$

San Francisco Bay subregion, temperatures $\ldots \ldots \ldots \ldots 48$

subsidence, Bunker Hill-San Timoteo area ... . . . . 209

Los Angeles County, Raymond Basin ......... 184 suspended-sand discharge, Sonoma County,

Russian River ....................... 58

water, East Fork Kaweah River basin, quality

and quantity $\ldots \ldots \ldots \ldots \ldots \ldots \ldots \ldots \ldots \ldots$

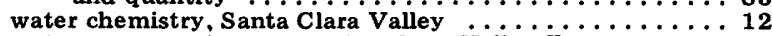

water-resources inventory, Antelope Valley-East

Kern Water Agency area, 1969-70 . . . . . . . . 229

water subsidence, Chino-Riverside and Bunker

Hill-Y ucaipa areas ................ 183

Canada, Edmonton to Prudoe Bay, Alaska, environment .... $\ldots 175$

Capture gamma rays, linear combination reading

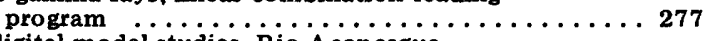

Chile, digital model studies, Rio Aconcagua

Valley ........................ 278

Chilean nitrates, composition, computer studies $\ldots \ldots \ldots \ldots 138$

Chromite, West Pakistan, Zhob Valley, Quetta Division, potential ..............242

Colorado, coal reserves, tabulation ............ 178

geologic map, Eagle, Lake, Pitkin, and Summit

Counties, Holy Cross quadrangle $\ldots \ldots \ldots \ldots \ldots 286$

Indian Hills quadrangle $\ldots \ldots \ldots \ldots \ldots \ldots \ldots \ldots \ldots \ldots$

Jackson County, Kings Cany on quadrangle .........

Jefferson and Clear Creek Counties, Bergen Park area ............................ 256

geologic reconnaissance, Archuleta County, Chris Mountain and Pagosa Springs quadrangles, map

Hinsdale and Archuleta Counties, Bear

Mountain and Oakbrush Ridge quadrangles,

map ......................... 141

La Plata County, Rules Hill and Ludwig Mountain quadrangles, map $\ldots \ldots \ldots \ldots \ldots \ldots 143$

ground-water reconnaissance, Rocky Mountain

National Park .................... 320

Shadow Mountain National Recreation area .........320

induced polarization, preliminary results $\ldots \ldots \ldots \ldots \ldots 159$
Colorado-Continued

landslide deposits, Jefferson County, Green Mountain area ................. 252

nahcolite, saline facies of Green River

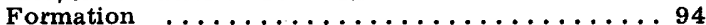

rainfall and runoff, Denver area $\ldots \ldots \ldots \ldots \ldots \ldots \ldots \ldots \ldots$

resistivity, Northgate district, preliminary

results ....................... 159

resistivity sections, Arkansas River basin $\ldots \ldots \ldots \ldots .337$

streamflow-data program, evaluation $\ldots \ldots \ldots \ldots \ldots .182$

Stroebel Spring, E1 Paso County, test $\ldots \ldots \ldots \ldots \ldots \ldots \ldots \ldots 157$

water supply, Curecanti Recreation area . . . . . . . 49

Colorado and Utah, base maps, Green River Formation, Uinta Basin . . . . . . . . . . . . . 308

water-resources investigations, Dinosaur

National Monument ............... 271

Colombia, laterite deposits and phosphate investigations, progress report $\ldots \ldots \ldots \ldots \ldots 65$

Columbia River estuary, radionuclides, distribution in bottom sediments ............... 121

Connecticut, Quaternary history, Broad Brook quadrangle, data $\ldots \ldots \ldots \ldots \ldots \ldots \ldots \ldots \ldots \ldots$

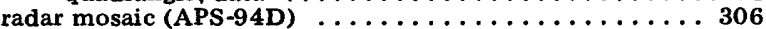

Still River Valley, glacial and drainage

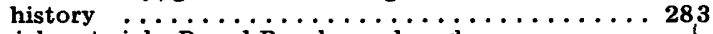

surficial materials, Broad Brook quadrangle,

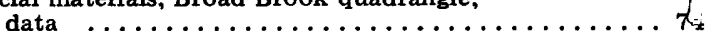

Connecticut-Massachusetts, geologic map, Hampden

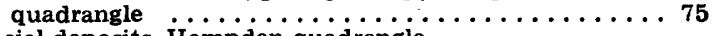

surficial deposits, $\mathrm{H}$ ampden quadrangle, analytical data $\ldots \ldots \ldots \ldots \ldots \ldots \ldots \ldots \ldots \ldots$

D

Delaware, exploratory well, near Greenwood, geologic and hydrologic data $\ldots . \ldots \ldots . . . .167$

$\mathbf{F}$

Florida, chemical and biological characteristics,

Upper St. Johns River basin ............ 124

draining Lake Apopka, hydrologic considerations $\ldots \ldots \ldots$

hydrologic conditions, Dade County, $1969 \ldots \ldots \ldots$ i55

Polk County, Lakeland Ridge area, preliminary

evaluation ...................241

hydrologic records, volusia County, 1970-71 ...... 181

hydrobiological characteristics, Shark River

estuary, Everglades National Park ... . . . . . . 199

remote sensing, investigation of vacant land $\ldots \ldots \ldots \ldots 98$

streamflow-data program, proposed $\ldots \ldots \ldots \ldots \ldots \ldots 230$

water and sewerage plans, Dade County,

hydrologic effects ................. 207

water quality, Cottonmouth Camp-Everglades

National Park, November 1969 ........... 200

Dade-Collier Training and Transition

Airport, November 1969 ............. 200

Miami International Airport, November $1969 \ldots \ldots 200$

Flow meter, open-channel integrating-type $\ldots \ldots \ldots \ldots \ldots 173$

Flumes, laboratory, designing aids $\ldots \ldots \ldots \ldots \ldots \ldots \ldots \ldots \ldots \ldots \ldots$

G

Georgia, fluvial sediment, North Fork Broad

River, subwatershed No, $14 \ldots \ldots . . . . . .107$

geology and water supply, Gordon, Whitfield,

and Murray Counties .............. 79

Gold, New Mexico, Socorro County, distribution . . . . . . 134

Gravity, vertical gradient in vertical and

near-vertical boreholes ..............42

Gulf of Maine, western sedimentary framework $\ldots \ldots \ldots \ldots 220$

H

Hawaii, floods, through September $30,1970 \ldots \ldots \ldots \ldots 97$

Heavy minerals, Alaska, near Nome, Pleistocene

and Holocene sediments ............ 257

continental shelf, northern Bering Sea $\ldots \ldots \ldots \ldots \ldots \ldots . \ldots \ldots$

I

Idaho, aeromagnetic map, Custer Elevenmile Creek,

Sunbeam, Thompson Creek, and

Clayton quadrangles . . . . . . . . . . . . . . 292

aeromagnetic map, Doublespring quadrangles ........ 291

Patterson and Leodore quadrangles $\ldots \ldots \ldots \ldots \ldots 293$ 
Idaho-Continued

geohydrologic sections, Cache Valley .......... 193

geologic map, Boundary County, Hall Mountain

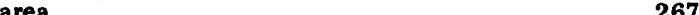

aeromagnetic map, southwestern part .......... 290

water quality, Snake Plain aquifer $\ldots \ldots \ldots \ldots \ldots \ldots 93$

Illinois, floods, Arlington Heights quadrangle $\ldots \ldots \ldots \ldots \ldots, 3$

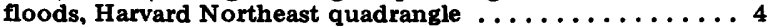

Harvard Southwest quadrangle . . . . . . . . . 214

Indiana, sediment investigations, progress report $\ldots \ldots \ldots \ldots 160$

Indonesia, central Java, geothermal energy, Dieng

Mountains, geochemical evaluation ....... 213

Dieng geochemical area, initial investigations $\ldots \ldots \ldots 285$

Infrared and color imagery, computer analysis of geographic phenomena $\ldots \ldots \ldots \ldots \ldots$

Infrared color photography, Apollo 9, land use

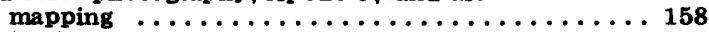

Douglas County, crop identification ........... 260

Infrared ektachrome, enhancement techniques, TR 69-6, 69-6A . . . . . . . . ....... 99

Infrared imagery, thermal study of Missouri River, North Dakota $\ldots \ldots \ldots \ldots \ldots \ldots \ldots \ldots \ldots \ldots 1$

$\mathbf{K}$

Kentucky, dolomite occurrences and structural features, Clark and Madison Counties.

Winchester quadrangle ................43

palynological investigations, Pennsylvanian, $\mathrm{vi} \ldots \ldots \ldots 174$

\section{$\mathbf{L}$}

Land use interpretation, TR $69-5 \ldots \ldots \ldots \ldots \ldots \ldots \ldots$ Lanthanum, New Mexico, Socorro County, distribution ... 130 Lead, New Mexico, Socorro and Sierra Counties, distribution .................. 131

New Mexico, Socorro County, distribution $\ldots \ldots \ldots \ldots 132$ Lead isotope geochemistry, $1967-69$, reference

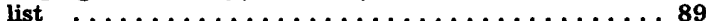

Liberia, aeromagnetic map, Bopolu quadrangle $\ldots \ldots \ldots \ldots 20$ aeromagnetic map, Buchanan quadrangle $\ldots \ldots \ldots \ldots 21$

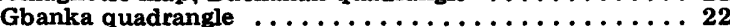

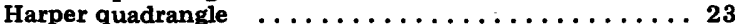

Juarzoa quadrangle $\ldots \ldots \ldots \ldots \ldots \ldots \ldots \ldots \ldots \ldots, 330$

Monrovia quadrangle $\ldots \ldots \ldots \ldots \ldots \ldots \ldots \ldots \ldots 24$

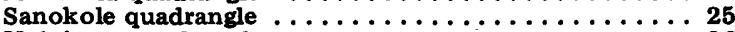

Voinjama quadrangle $\ldots \ldots \ldots \ldots \ldots \ldots \ldots \ldots 26$

Zorzor quadrangle $\ldots \ldots \ldots \ldots \ldots \ldots \ldots \ldots \ldots \ldots \ldots \ldots \ldots \ldots$

Zwedru quadrangle $\ldots \ldots \ldots \ldots \ldots \ldots \ldots \ldots \ldots \ldots, 331$

Bouguer anomaly map, Monrovia quadrangle $\ldots \ldots \ldots 28$

gamma radiation map, Bopolu quadrangle $\ldots \ldots \ldots \ldots \ldots 29$

Buchanan quadrangle $\ldots \ldots \ldots \ldots \ldots \ldots \ldots \ldots \ldots \ldots$

Gbanka quadrangle $\ldots \ldots \ldots \ldots \ldots \ldots \ldots \ldots \ldots \ldots, 31$

Harper quadrangle $\ldots \ldots \ldots \ldots \ldots \ldots \ldots \ldots \ldots \ldots \ldots \ldots \ldots \ldots \ldots \ldots, 32$

Juazohn quadrangle $\ldots \ldots \ldots \ldots \ldots \ldots \ldots \ldots \ldots \ldots, \ldots \ldots \ldots$

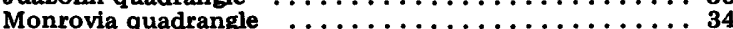

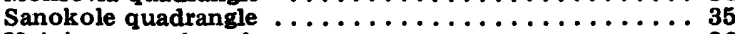

Voinjama quadrangle $\ldots \ldots \ldots \ldots \ldots \ldots \ldots \ldots \ldots \ldots, 36$

Zorzor quadrangle $\ldots \ldots \ldots \ldots \ldots \ldots \ldots \ldots \ldots \ldots \ldots \ldots$

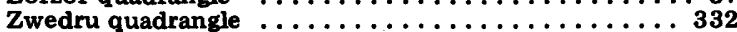

Louisiana, stream contaminants, Mississippi River below Baton Rouge, time measurements ......996

streamflow-data program, proposed $\ldots \ldots \ldots \ldots \ldots \ldots 77$

Lunar-surface pictures, Apollo $14 \ldots \ldots \ldots \ldots \ldots \ldots \ldots 17$

\section{M}

Maryland, analog model study, Magothy aquifer . . . . . 194 test well, near Chestertown, geologic and hydrologic data ........ 168

waste transport, Muddy Creek-Rhode River estuary, tracer simulation ............ 336

Massachusetts, southeastem offshore area, sedimentary framework ...............220

water supply, A uburn, salt contamination $\ldots \ldots \ldots \ldots 227$

Massachusetts-Connecticut, geologic map, Hampden quadrangle ................ 75

surficial deposits, Hampden quadrangle, analy tical data $\ldots \ldots \ldots \ldots \ldots \ldots \ldots \ldots \ldots$

surficial deposits, Hampden quadrangle, analytical data $\ldots \ldots \ldots \ldots \ldots \ldots \ldots \ldots \ldots \ldots$

Michigan, geologic map, Greenwood quadrangle . . . . . . 62 geologic map, Marquette County, Ishpeming quadrangle $\ldots \ldots \ldots \ldots \ldots \ldots \ldots \ldots \ldots \ldots \ldots .259$

Negaunee Southwest quadrangle $\ldots \ldots \ldots \ldots \ldots \ldots \ldots \ldots 6 . \ldots \ldots$

Republic quadrangle $\ldots \ldots \ldots \ldots \ldots \ldots \ldots \ldots \ldots .63$
Michigan-Continued

Jacobsville sandstone, Ontonagon County, Rockland and Greenland quadrangles, erosion surface . ................... 324

Keweenawan geology, Isle Royale ........... 154

Mineral prospecting techniques, geochemical, botanical, geophysical, and remote sensing, tropical areas $\ldots \ldots \ldots \ldots \ldots \ldots \ldots . \ldots$

Minnesota, stream-flood investigations . . . . . $139 \ldots \ldots . .197$

water resources, Red River $\ldots \ldots \ldots \ldots \ldots \ldots \ldots \ldots \ldots \ldots$

Mississippi, ground-water program $\ldots \ldots \ldots \ldots \ldots \ldots \ldots \ldots \ldots \ldots$

surface water, Pat Harrison Waterway District, quality $\ldots \ldots \ldots \ldots \ldots \ldots \ldots \ldots \ldots$. . . . . . . . . .

Missouri, flood-frequency estimates for urban areas $\ldots \ldots \ldots \ldots \ldots \ldots \ldots$ County, Coldwater Watkins Creek, and River Des Peres basins $\ldots \ldots \ldots \ldots \ldots \ldots$ Mexico, Socorro County,

Molybdenum, New Mexico, Socorro County,
distribution $\ldots \ldots \ldots \ldots \ldots \ldots \ldots \ldots \ldots$

Montana, aeromagnetic map, Stillwater complex ...... 295

discharges from small drainage areas $\ldots \ldots \ldots \ldots \ldots 161$ geologic map, Gallatin and Park Counties,

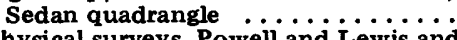

geophysical surveys, Powell and Lewis and Clark Counties, Lincoln Back Country area .................................

mineral resources, Powell and Lewis and Clark

Moon, Apollo 9, infrared color photography, land

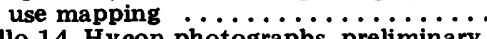

Apollo 14, Hycon photographs, preliminary study ................................ 152

landing site, geologic investigations $\ldots \ldots \ldots \ldots \ldots \ldots 274$

lunar-surface pictures $\ldots \ldots \ldots \ldots \ldots \ldots \ldots \ldots \ldots \ldots 17$

review and analysis $\ldots \ldots \ldots \ldots \ldots \ldots \ldots \ldots \ldots \ldots 19 \ldots \ldots \ldots \ldots$

sample documentation $\ldots \ldots \ldots \ldots \ldots \ldots \ldots 272,273$

traverse map $\ldots \ldots \ldots \ldots \ldots \ldots \ldots \ldots \ldots \ldots 297$

Apollo 15, landing site, geology and field petrology, preliminary report $\ldots \ldots \ldots \ldots \ldots \ldots . \ldots 305$

landing site, relief map $\ldots \ldots \ldots \ldots \ldots \ldots \ldots \ldots . \ldots 304$ samples, preliminary documentation $\ldots \ldots \ldots \ldots \ldots 273$ surface operational maps $\ldots \ldots \ldots \ldots \ldots \ldots \ldots . \ldots 307$

pictures, preliminary catalog $\ldots \ldots \ldots \ldots \ldots \ldots \ldots 18$

Fra Mauro landing site, traverse map ........ 219 geologic map, Schickard quadrangle $\ldots \ldots \ldots \ldots \ldots \ldots \ldots \ldots$ near side, geologic provinces $\ldots \ldots \ldots \ldots \ldots \ldots \ldots \ldots, 189$ two former faces $\ldots \ldots \ldots \ldots \ldots \ldots \ldots \ldots \ldots \ldots \ldots \ldots$

$\mathbf{N}$

Nebraska, streamflow, Shell Creek, Elkhorn River, and Salt Creek basins $\ldots \ldots \ldots \ldots \ldots$

Nevada, geochemical data, Esmeralda County, Sixteen-to-One mine $\ldots \ldots$. . . . . . . Goldfield mining district ...........

Lander County, Battle Mountain mining district $\ldots \ldots \ldots \ldots \ldots \ldots \ldots \ldots \ldots \ldots \ldots \ldots 28$

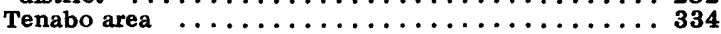

New Hampshire, deglaciation events, Manchester

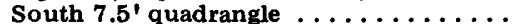

New Jersey, floods, Crosswicks Creek, extent and frequency $\ldots \ldots \ldots \ldots \ldots \ldots \ldots \ldots \ldots \ldots$. . . . .

New Jersey-Pennsylvania, geology, Stroudsburg quadrangle ........................... and silver, lead, molybdenum, niobium and gold, strontium, tin, zinc and antimony, Socorro County . . . . . 129, 130, 132-137

distribution of beryllium and lead, Socorro and Sierra Counties . $\ldots$ M 3 Kiniey

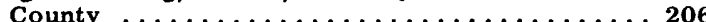

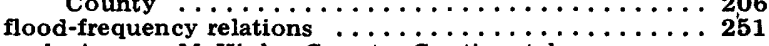

geologic map, McKinley County, Continental

Divide quadrangle $\ldots \ldots \ldots 126 \ldots \ldots$

microclimate, Carlsbad Caverns $\ldots \ldots \ldots \ldots \ldots \ldots 198$

Morrison Formation, stratigraphy $\ldots \ldots \ldots \ldots \ldots \ldots 245$

Pecos River, depletions, losses, and gains $\ldots \ldots \ldots \ldots \ldots 236$

south-central, aeromagnetic map ........... 288

Triassic fauna and flora, bibliography $\ldots \ldots \ldots \ldots \ldots .333$

water level in shallow aquifer, Chaves and Eddy Counties, Roswell basin, map

water-resources, White Sands Missile Range,

annual review $\ldots \ldots \ldots \ldots \ldots \ldots \ldots \ldots \ldots \ldots$

water supply during STARMET test, investigation $\ldots \ldots \ldots 16$ 
New York, floodflow characteristics, Poultney River,

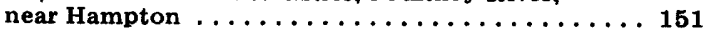

Niobium, New Mexico, Socorro County, distribution ..... North Carolina, sedimentation, Third Creek Subwatershed

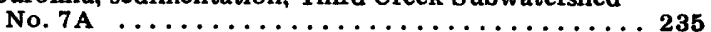
streamflow-data program, proposed $\ldots \ldots \ldots \ldots \ldots \ldots \ldots \ldots$

North Dakota, geologic map, Morton County, Dengate

quadrangle $\ldots \ldots \ldots \ldots \ldots \ldots \ldots \ldots$
thermal study of Missouri River by infrared imagery $\ldots \ldots \ldots \ldots \ldots \ldots \ldots \ldots \ldots \ldots$

\section{$\mathbf{0}$}

Ohio, low-flow study, southwest streams Oregon, coastal terraces, Coos and Curry Counties, erosion and soil formation $\ldots \ldots \ldots \ldots$

gaging stations, October 1952-September 1970

data compilation 1952 Sept

mineral resources, near Eagle Cap wildemess $\ldots \ldots \ldots \ldots . \ldots \ldots$

streamflow, Washington County, Tualatin River

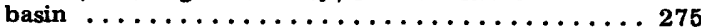

$\mathbf{P}$

Pennsylvania, Bald Eagle Creek and West Branch Susquehanna River, Clinton County, acidity control $\ldots \ldots \ldots \ldots \ldots \ldots \ldots \ldots \ldots 108$

chemical and biological conditions, Bald Eagle

Creek ............................ 109

Foster Joseph Sayers Reservoir, trophic characteristics .................. 109

sediment yield, near Harrisbury, construction effects ............... 234

Pennsylvania-New Jersey, geology, stroudsburg quadrangle $\ldots \ldots \ldots \ldots \ldots \ldots \ldots \ldots \ldots \ldots \ldots$

Photography, space, identification of transportation

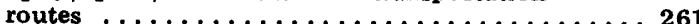

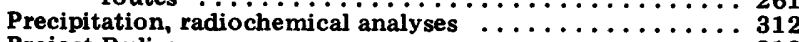

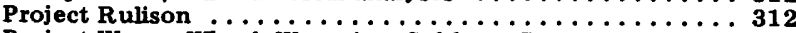

Project Wagon Wheel, wyoming, Sublette County, water well No. 1, hydraulic tests ........... 311

Puerto Rico, copper-mine tailings, Rio Tanama

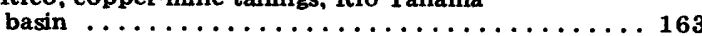

geologic map . . . . . . . . . . . . . . . 78

hornblende-plagioclase in trusives, Ponce quadrangle $\ldots \ldots \ldots \ldots \ldots \ldots \ldots \ldots \ldots \ldots \ldots \ldots \ldots$

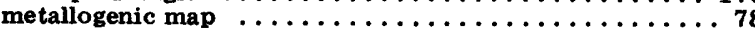

water, Guayama area, electric analog model study . . . 86

Rio Tanama basin . . . . . . . . . . . . . 163

Yabucoa Valley, electrical analog model

study, phase $1 \ldots \ldots \ldots \ldots \ldots \ldots \ldots \ldots \ldots \ldots$

water records, 1964-67 ................239

$\mathbf{R}$

Radar mosaic (APS-94D), Connecticut and Rhode Island . . 306 Radiation emission, terrestrial, mapping with RS-14

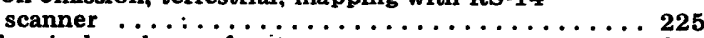

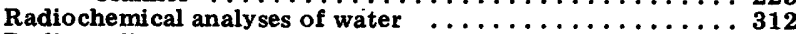

Radionuclide content, Columbia River sediments . . . . . 153

Rhode Island, radar mosaic (APS-94D) $\ldots \ldots \ldots \ldots \ldots . \ldots 306$

\section{$\mathbf{S}$}

Saudi Arabia, geochemical maps, Samrah and vicinity $\ldots 281$ meteorite fall, near Sakakah .............. 127 mineral investigations, Najd quadrangle,

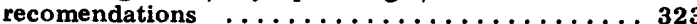

molybdenite, Al Kushay miy ah $\ldots \ldots \ldots \ldots \ldots \ldots \ldots \ldots \ldots \ldots$

Silver, New Mexico, Socorro County, distribution $\ldots \ldots \ldots 130$

Silver deposits, Alaska Skagway B-4 quadrangle, analy ses and geologic summary ........... 195

South Dakota, artesian wells, northern Black Hills, head fluctuations . . . . . . . . . . . 1

glacial outwash aquifer between Sioux Falls

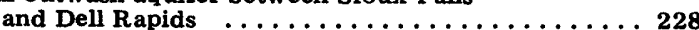

Springs, radiochemical analyses $\ldots \ldots \ldots \ldots \ldots \ldots \ldots \ldots \ldots \ldots \ldots \ldots \ldots$

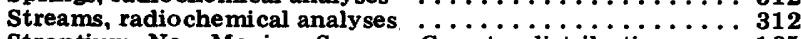

Strontium, New Mexico, Socorro County, distribution $\ldots 135$

\section{$\mathbf{T}$}

Taiwan, monazite $\ldots \ldots \ldots \ldots \ldots \ldots \ldots \ldots \ldots \ldots \ldots \ldots$

Tellico test site, land use map $\ldots \ldots \ldots \ldots \ldots \ldots \ldots \ldots \ldots \ldots, 329$
Tennessee, streams, peak stages and discharges . . . . . 325

Texas, hydrologic data, A ustin, urban studies . . . . . 240 hydrologic data, Brazos River basin, Green

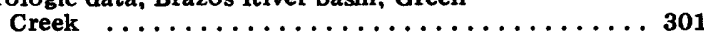

Calaveras Creek, San Antonio River basin .........

Colorado River basin, Deep Creek $\ldots \ldots \ldots \ldots \ldots 148$

Cow Bayou, annual compilation ...................

Deep Creek, Colorado River basin .......... 300

Elm Fork Trinity River, annual compilation ....... 244

Escondido Creek, San Antonio River basin ....... 232

Fort Worth, urban studies $\ldots \ldots \ldots \ldots \ldots \ldots \ldots \ldots .84$

Green Creek, Brazos River basin ............. 201

Mountain Creek, Trinity River basin . . . . . . . . 60

Mukewater Creek, Colorado River basin . . . . . 149

North Creek, Trinity River basin $\ldots \ldots \ldots \ldots \ldots \ldots 170$

Pin Oak Creek, Trinity River basin .......... 303

San Antonio River basin, Calaveras Creek . . . . . . 299

Trinity River basin, Honey Creek .......... 302

Pin Oak Creek ........................

hydrology, urban, data compilation $\ldots \ldots \ldots \ldots \ldots \ldots 162$

stream floods and discharges $\ldots \ldots \ldots \ldots \ldots \ldots \ldots 249$

streamflow-data program, proposed $\ldots \ldots \ldots \ldots \ldots \ldots \ldots \ldots$

surface water stations, October $1971 \ldots \ldots \ldots \ldots \ldots \ldots \ldots \ldots$

Tin, New Mexico, Socorro County, distribution . . . . 136

\section{$\mathbf{U}$}

United States, southeastern, fluvial monazite deposits $\ldots \ldots \ldots \ldots \ldots \ldots \ldots \ldots \ldots \ldots \ldots 22$

U.S. and U.S.S.R., nuclear explosion sites, environments .................279

Utah, geohydrologic sections, Cache Valley $\ldots \ldots \ldots \ldots 193$

infrared imagery and color photography, geologic evaluation $\ldots \ldots \ldots \ldots \ldots \ldots \ldots \ldots \ldots 140$

streamflow-data program, proposed .......... 322

U.S. Geological Survey Central Laboratory $\ldots \ldots \ldots \ldots 188$

west-central, aeromagnetic map $\ldots \ldots \ldots \ldots \ldots \ldots \ldots \ldots \ldots$ Utah and Colorado, base maps, Green River

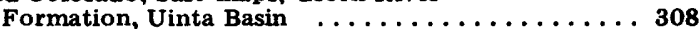

water-resources investigations, Dinosaur National Monument ..............271

V

Virginia, flood frequency, small streams

Virgin Islands, U.S., geology of insular shelf. south of St. Thomas and St. John south of St. Thomas and St.

Washington, ground water, near Bel Bay development, Lummi Indian Reservation $\ldots \ldots \ldots \ldots \ldots \ldots 296$ microearthquake activity, Wooded Island, Hanford region ................... 226

radioactive waste storage, Hanford Reservation, hydrologic factors . . . . . . . . . . . . 180 stream-sediment transport, Snohomish River

basin ...................... 215

Water, polluted, separation and identification of phenolic compounds ................ 100

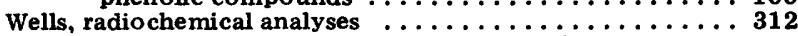

West Pakistan, geology and chromite potential,

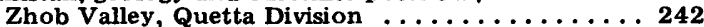

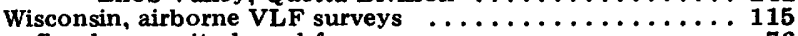

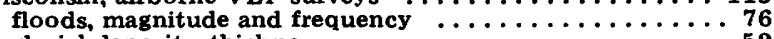

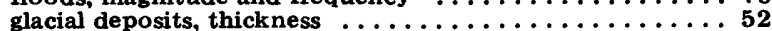

hydrology, Hulbert Creek ............... 118

Precambrian geology, 1778-1968, bibliography $\ldots \ldots \ldots 92$

well yields, from bedrock $\ldots \ldots \ldots \ldots \ldots \ldots \ldots \ldots$

from glacial deposits . . . . . . . . . . . . . 51

Wyoming, geologic map, Lincoln, Sublette, and Teton Counties, Clause Peak quadrangle .......... 250

geologic map, Teton County, Mount Bannon quadrangle ..................... 233

hydraulic tests, water well No. 1 , Sublette County, Project Wagon Wheel . . . . . . . . 311 southeastern, water, chemical quality $\ldots \ldots \ldots \ldots \ldots \ldots 298$ time-of-travel measurements, Wind/Bighorn

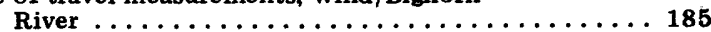

\section{$\mathbf{z}$}

Zinc, New Mexico, Socorro County, distribution $\ldots \ldots \ldots 137$ 